\title{
日本泌尿器科學會雜誌
}

\author{
第 34 卷 第 2 號 昭和 18 年 (1943) 2 月
}

原萻

\section{諸種「ホルモン」劑ノ雄性海猽生殖器ノ 發育二及ボ入實驗的研究}

T. Asahara: Experimentelle Studien über die Einflüsse der endokrinen Organextrakte auf das Wachstum der männlichen

Geschlechtsorgane des Meerschweinchens.

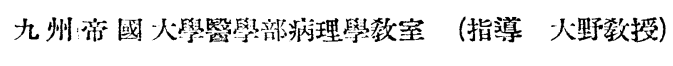

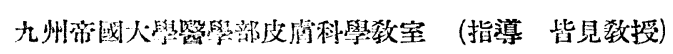

軎攻生朝原達雄

\section{筑 1 章 緒論}

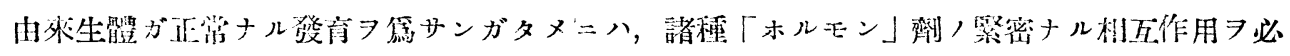

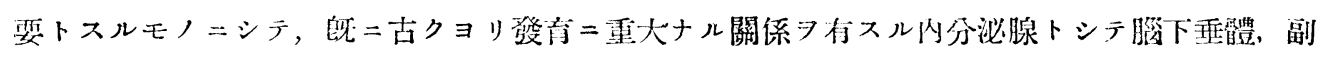

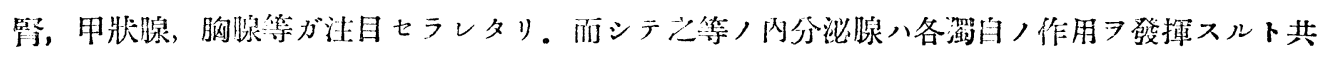

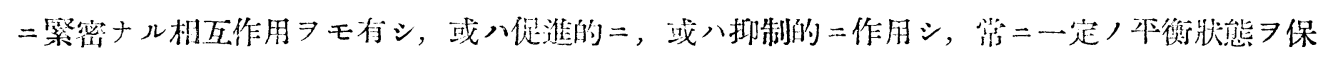

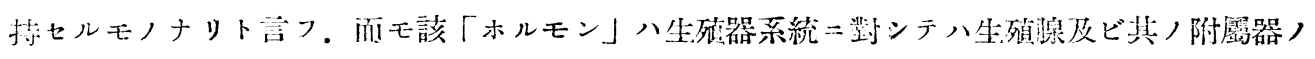

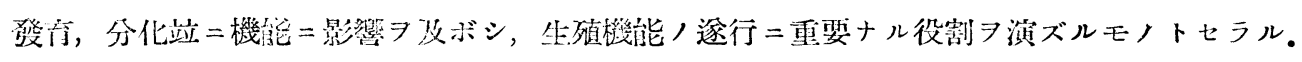

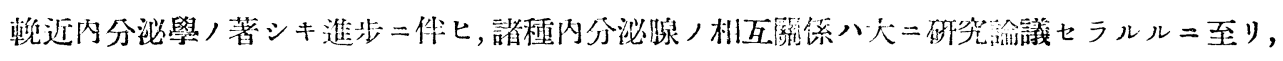

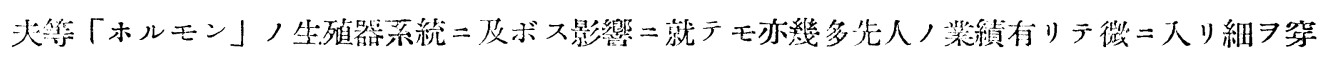

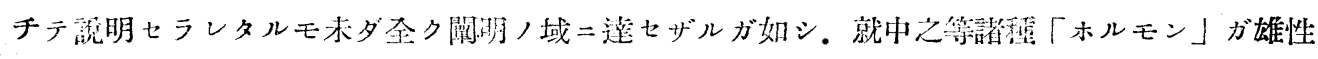

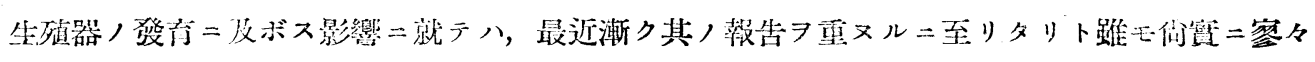

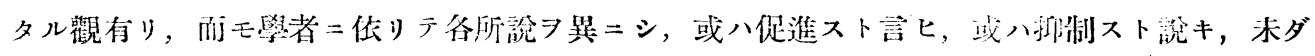
其ノ一致ヨ見ザルノえナラズ, 促進作用有りト主張スルモノモ, 其, 䛨新ナル事項二關シテハ

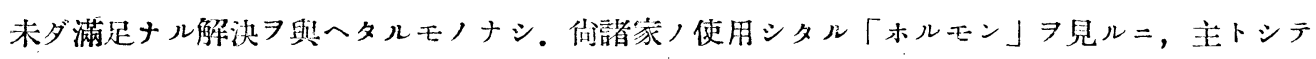

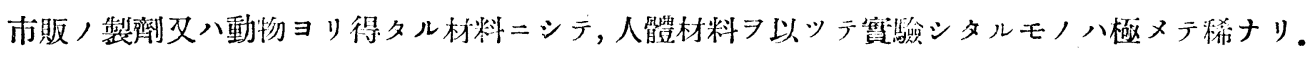

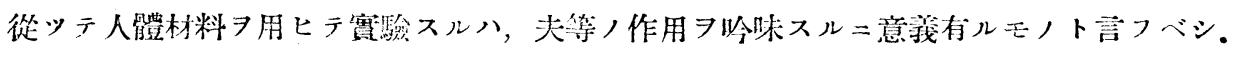


而シテ「ホルモン」ハ其ノ作用ヨ發揮スルニ常りテハ,種々ノ要約二支配セラル、モノニシテ， 個體二依りテ各感受性ノ等シカラザルハ勿論, 動物ノ種族，年龄，性別，「ホルモン」ノ種類，又

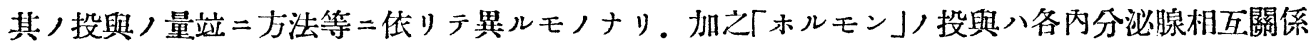

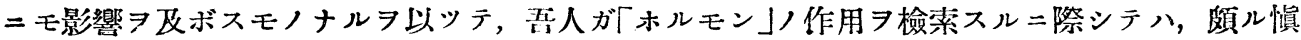
重ニ之ア取扱フ要有ルハ多言フ侯タズ. 就中發育, 分化ノ過程 7 嚴密二且系続的二探究セント 欲セバ，實驗動物ノ可及的幼若未熟ニシテ，未ダ自體ノ内分泌機能ノ發現セザルカ或八極メテ 其ノ微弱ナル時期 =於テ之ヨ行フタ至常ト信ズ。サレバ新產仔八以上ノ目的二最モ適合シタル モノト言フペシ.

余八凡ソ雄性生殖器ノ發育二關係习有スベキ諸種「ホルモン」/作用

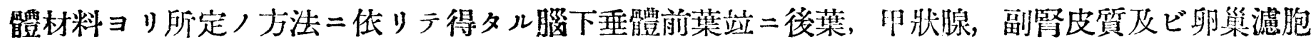

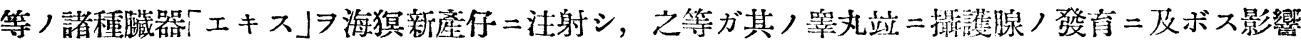

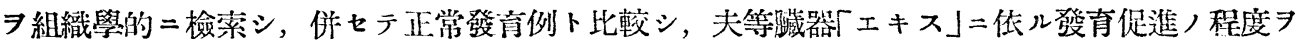
䦐明セント企圖セルモノナリ。

\section{第 2章 實 驗 方 法}

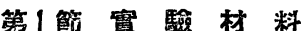

本賽驗二使用セシ注射材料入當蒋理祭教室二テ

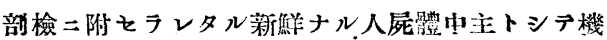
能旺盛ナル青壯年期ノ男女ヨy得タル腦下垂體前 葉, 後菜, 副腎皮質, 甲界腺及ビ卵巢滤胞二就キ 其ハエキス」キ作レルモノニシテ，夫等ノ處置法 八大粎次 如シ。

\section{第 2 䉪「エキス」/製法}

第 1 項 腦下垂體前葉及ビ後菜「エキス」新鮮 シシテ且著變ナキ腦下垂體キ先ッ゙前蕉ト後葉トニ 可及的嚴密二分離シ，別個二之キ純「アをトン」中 ニ入レ, 3-5日間放置シ,之イデ之キ濾紙上二掂 タ゚一定度乾燥七シメタル後更二細片トナシ，数日 間室溫二放嘿シ，充分乾燥スルキ待チテ等鉢二入 レ入念二磨碎入。該粉末へ引濨セザル栐保存セり。

使用二際シテ八該粉末キ滅菌生理的食篮水キ以 ツテ $1 \%$ 溶液トシ，之二「クロロフォルム」/適最 キ加へテ腐败キ防ギ， 1 學夜水室二保存シ，有效 成分ノ充分淩出スルキ待チア遠心器二カタ, 其, 上澄探りテ注射二供七り。

第 2 項 副腎皮質「エキス」副監ハ之キ可及的

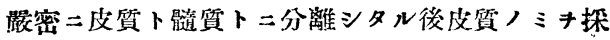
yテ前訅同核二處置シタッ。

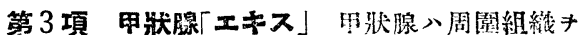
充分二除去シタル後之キ細片トナシ前訅问漛ノ處 坚キトレタ。

管 4 項 卵巢滤狍「エキス」黄體キ出來得儿限

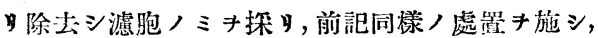
前 4 者卜同一悠件ノ下ニ「xキス」キ作製七り。

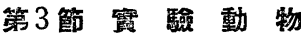

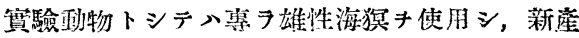
仔ョリ生娞 60 日迄ノモノキ一定期間敗群二分チテ 對照滓卜シタル以外入新產仔入，之生後 5 !! 日

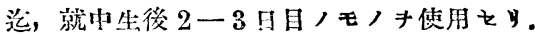

\section{第4筯 注射方法及ビ注射量}

注射八專ラ皮下注射卜シ，注射ノ形式八前記榙 種「エキス」ノ0.3 cc及级じ0.6cc キ原則トシテ 1 -2 週间每日洼射シ，洼射終了後柆日屡殺七り。其， 他最終注射ノ效カキ充分筑揮セシメンガタメ注射 終了後 7 日目二居殺七シモノアリ。此等 2 群二分 チ實驗セル注射總最ハ表中二之キ訅載セリ。

\section{第5箕 測 定 方 法}

體重及ビ各䠞器/重意ハ $\mathrm{g}$ キ單位トシテ之キ測 定シタタ。但シ各贜器/重量入凡テ10\%「フォル マタン」液キ以ッテ固定シタル後二之キ測定シ ルモノナタ。 
第6 節 標 本 作 製

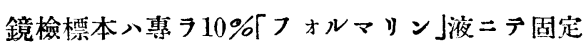
シ,「ツメロイヂン」切扸トタル後「ヘマトキシ

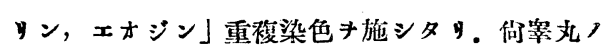
標本ハ凡テ右侧ノモノニ就キ之キ作䇝セリ。

\section{第3章 實 驗 成 績 \\ 第 1 節 記載方法二就テ}

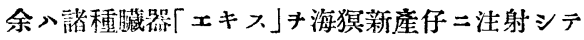

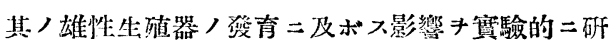
究シタルモノナルガ, 主トシテ學丸及ビ㩑護腺二 就テ逝ヘン。何生殖腺以外, 内分泌腺二就テハ剖 檢時肥大或入充血等多少見ル可キ所見キ得タルモ 其ノ詳細ナル發表入他ノ機會二変ル事トをン。

第 1 項 體雷 體重入注射前每目空腹時二之7 测定シタルモ，表り二八注射開始前及七゙屠殺時二

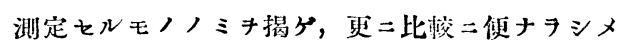
ンガタメ體重堆加率キ求メ之キ併訅セり。

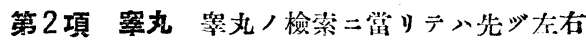

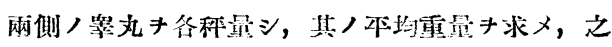
キ對照群ノ夫レト比校シ重理獒加率キ算出々リ。

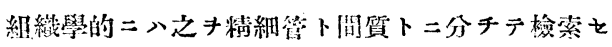
リ。其ノ棓細ハ姬娠尿「ホルモン」キ以ツテをル赛 驗報台二悉セルキ以ツテ之キ省略入。

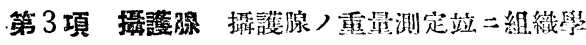
的所見二就テハ妊㛺尿「ホルモン」キ以ッテュル賽

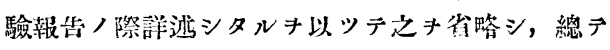

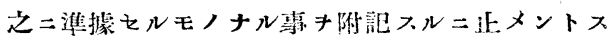

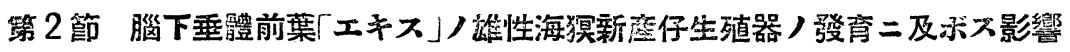

第 1 項 交献ノ概要 腦下垂體卜坐殖腺卜關 係ハ既ニ古クョリ注目をラレシ所ナルモ，1912年 Aschner, Ascoli u. Legnani 等/剔出試驗车螕 始メテ雨者ノ關係二磪定的根掉キ得タルモノト蓄 フベシ.

Evans \& Simpson (1926) 八幼落「アッフ」=牛腦

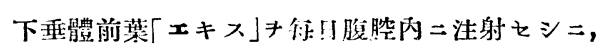
身體發有八落明ナラズジ, 絮丸儿重是八減ジ, 精細管入狹小トナy，页二阫種部ニモ一定ノ退行 性病變キ見タタト言フ。 $\operatorname{Biedl}(1927)$ ハラッテ」 及ビ「マウス」临下垂體前菜ノ移榅及ビ其ノ「エ

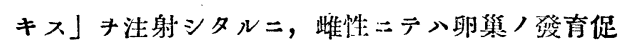

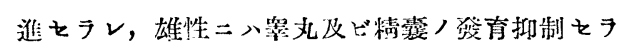
レタルキ磪メタルキ以ツテ, 胉下垂體前蕉入罢九 二對シテハ抑制的二作用シ, 卵嶣二八促進的二作 用スルモノナラント結諭セり。之二反シテ Sinith \& Engle (1927) 八腦下垂體剔出後二罢好八變性现 象キ見タルモ，腦下垂體ノ移椬二依りテ之が四得

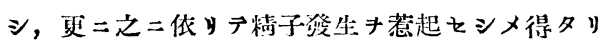
卜言と, Voss \& Loewe (1928) 八羊ノ前蕉キ「マウ

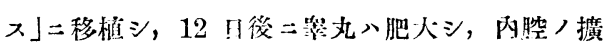

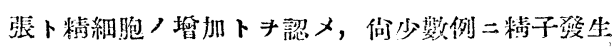

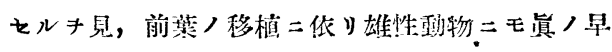
期成熟滤起スルモノナラント言へリ。 Belawenetz (1930) 入Pituitrin A.*级街

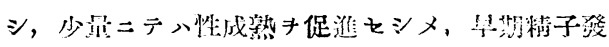

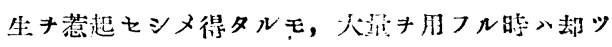
テ其ノ抑制セラルルキ見タリ。

Steinach u. Kun (1928) 八牛ノ前䔬「エキス」キ

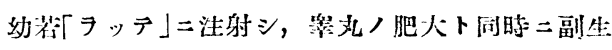

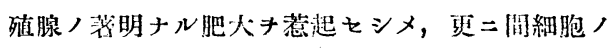

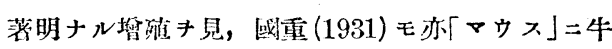

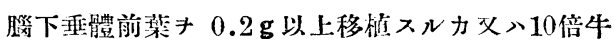

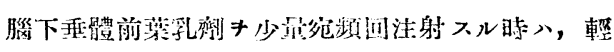

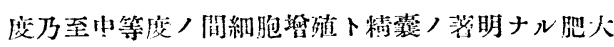
トキ惹起スルモノナリト記載セリ。㮦根 (1934) 、 牛腦下垂體前暴/ $5 \%$ 水溶「メキス」キ未器家兔二

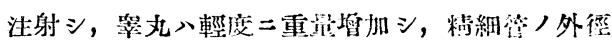
玉輕茫二增加シ，造精機轉玉亦之等二本行シテー

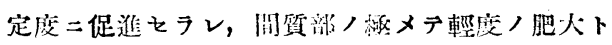

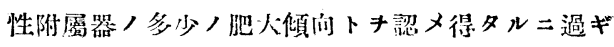
ズト言ヘリ.

\section{第 2 項 貿 驗 成 綪}

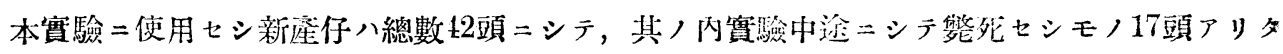




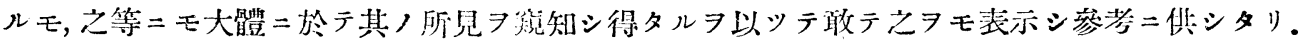

第 1 表 對 照 群

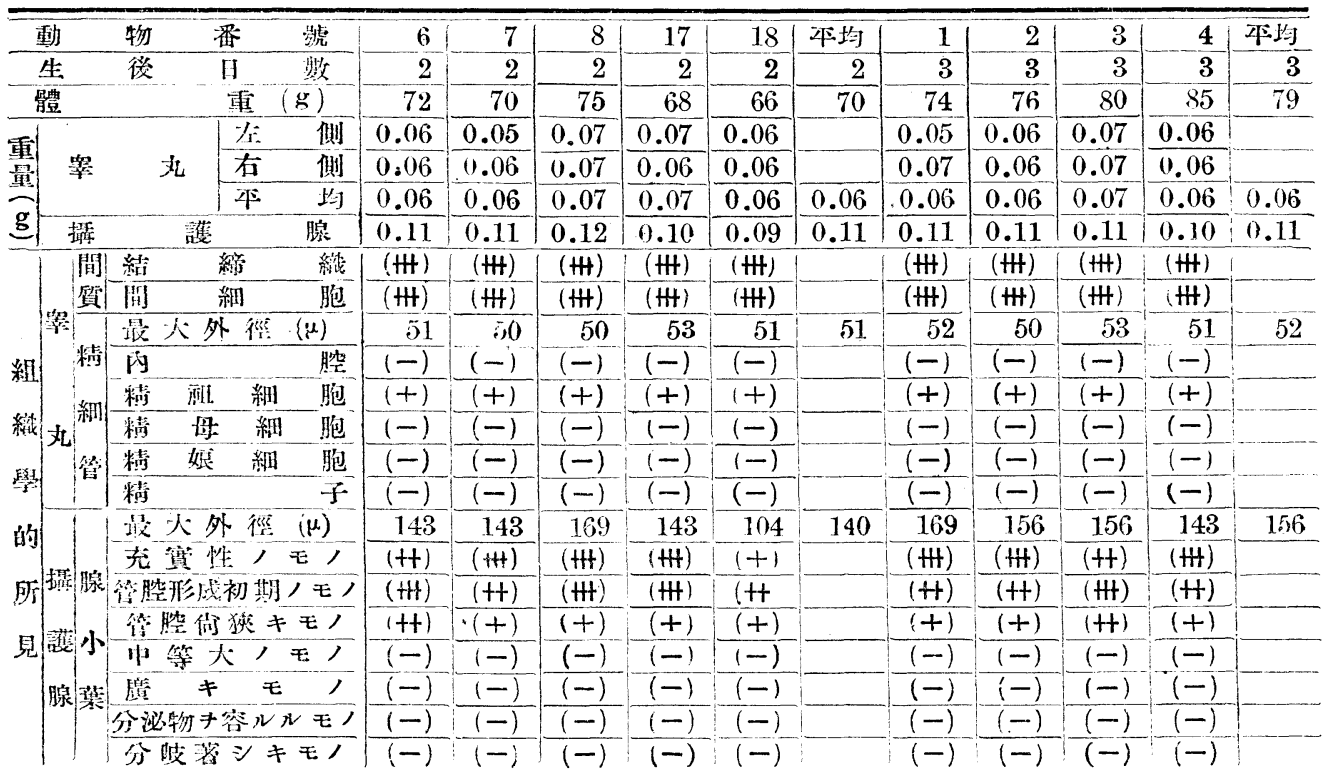

\begin{tabular}{|c|c|c|c|c|c|c|c|c|c|c|c|c|}
\hline 動 & 物 & 10 & 23 & 24 & 25 & F均 & 14 & 15 & 20 & 21. & 30 & P均 \\
\hline 生 & 後 & 10 & 10 & 10 & 10 & 10 & 1 & $i$ & 17 & 17 & 17 & 17 \\
\hline 體 & 重 & 10 & 110 & 10 & 102 & 106 & 12 & & 120 & & 60 & 120 \\
\hline \multirow{4}{*}{ 賽 } & 僋 & \multirow{2}{*}{0.10} & \multirow{2}{*}{$\frac{0.199}{0.09}$} & \multirow{2}{*}{$\frac{0.07}{0.09}$} & \multicolumn{2}{|l|}{0.08} & 0.11 & .11 & \multirow{2}{*}{$\frac{0.11}{0.11}$} & 2 & \multicolumn{2}{|l|}{0.10} \\
\hline & 如右 & & & & 0.08 & & .11 & ) & & 2 & \multirow{2}{*}{.11} & \\
\hline & 平 & 10 & \multirow{2}{*}{$\frac{0.09}{0.15}$} & 0.08 & .08 & .09 & 11 & 6 & 0.11 & 2 & & .11 \\
\hline & 護 腺 & 0.18 & & 0.14 & 0.13 & 0.14 & 0.18 & 0.17 & 0.16 & .18 & .16 & 0.17 \\
\hline 開 & 紹 & (1\#) & $(\mathrm{HH})$ & in) & (All) & & H) & +1 & +1 & $+t$ & t+) & \\
\hline & 細 & $(t+)$ & $(t+)$ & $(t+)$ & $(t+)$ & & (t+) & $(t+)$ & $(+t)$ & (H) & (t+) & \\
\hline & 昨大外膲 $(\mu)$ & 58 & 59 & 59 & 59 & $5 !$ & 65 & 64 & 62 & 63 & 68 & 64 \\
\hline & & (小) & (小) & (小) & (小) & & (小) & (小) & (小) & (小) & (小) & \\
\hline & 精 社 & $(+)$ & $(+)$ & $1+1$ & $(+)$ & & $(t+)$ & $(\mathrm{H})$ & $(t+)$ & $(t+)$ & $(t+)$ & \\
\hline & 精 贯 & $(-)$ & $(-)$ & $(-)$ & $(-1)$ & & $(-)$ & $(-)$ & $(-1)$ & $(-)$ & $( \pm)$ & \\
\hline & 檑 艮 & $(-)$ & $(-)$ & $(-1)$ & $1-1$ & & $(-)$ & $(-)$ & $(-)$ & $(-)$ & $(-)$ & \\
\hline 學 & 耪 & $(-)$ & $(-1$ & $(-)$ & $(-)$ & & $1-1$ & $(-)$ & $(-)$ & $(-)$ & $(-)$ & \\
\hline 的 & 最大外䀠 $(\mu)$ & 156 & 169 & 195 & 169 & 17 & 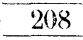 & 16 & 260 & 208 & 195 & 208 \\
\hline & 充算性， モ， & $(+)$ & $(+)$ & $(+t)$ & $(+t)$ & & $(+)$ & $(t+)$ & $(+)$ & $(+)$ & $(t+)$ & \\
\hline D & 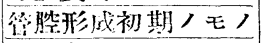 & (ttH) & +4 & $(\mathrm{tt})$ & (H) & & $(t+)$ & $(t+)$ & $(t+)$ & $(t+)$ & $(+t)$ & \\
\hline & 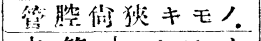 & $(t+)$ & (HI) & (冊) & (H) & & (HA) & (tH) & $(t+)$ & (HA) & (tH) & \\
\hline & 中等大ノモ， & $(+)$ & $(+1)$ & $( \pm)$ & $(-)$ & & $1 t$ & $( \pm)$ & $(+)$ & $(t+)$ & $(+)$ & \\
\hline & 廣 & $(-)$ & $(-)$ & $(-1)$ & $(-)$ & & $(-)$ & $(-)$ & $( \pm)$ & $(+)$ & $(-)$ & \\
\hline & 分泌物*容Nルモ， & $(-1)$ & $(-)$ & $(-)$ & $(-)$ & & $(-)$ & $( \pm)$ & $(-)$ & $(-)$ & $(-)$ & \\
\hline & & $(-$ & $(-)$ & $(-)$ & - & & $( \pm)$ & -1 & -1 & $(+)$ & () & \\
\hline
\end{tabular}




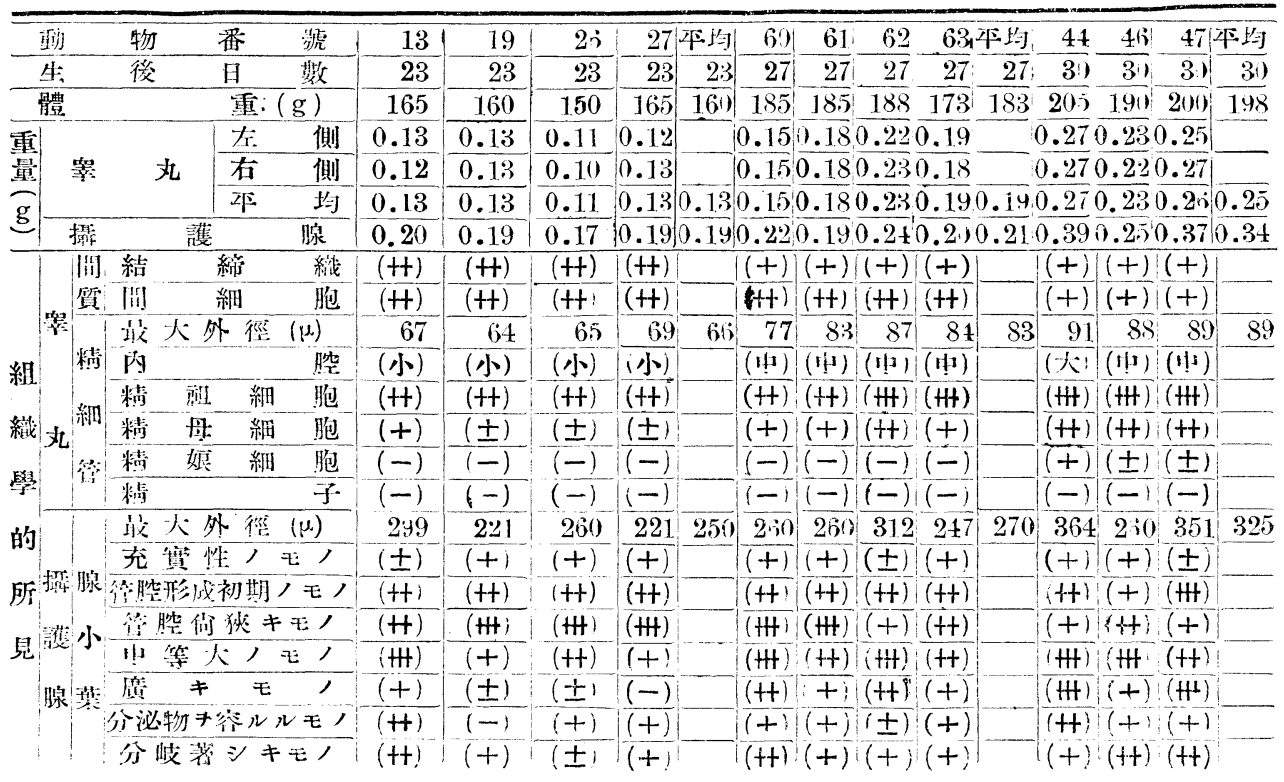

\begin{tabular}{|c|c|c|c|c|c|c|c|c|c|c|c|c|c|}
\hline Ir: & $4 t$ & 50 & 51 & 52 & F均 & 35 & 36 & 34 & 制 & \multirow{2}{*}{\multicolumn{2}{|c|}{ 40 $\quad 40$}} & \multirow{2}{*}{\multicolumn{2}{|c|}{ 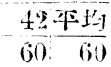 }} \\
\hline 牛: & 後 & 40 & 4 & 40 & 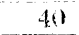 & & & 51 & 50 & & & & \\
\hline 體 & 再 $(\mathrm{g})$ & $260^{-}$ & 25 & 23 & & 28 & 290 & $2+3$ & $28 x$ & 330 & 840 & 325 & 332 \\
\hline & 主 侧 & .45 & .37 & 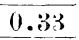 & & 43 & & .45 & & 0.77 & 0.57 & 0.69 & \\
\hline 冰 & 侧 & 45 & 0 & 0. & & & () & 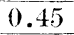 & & 0. & 0.70 & 79 & \\
\hline & 平 & $0 . \overline{45}$ & 0.37 & 8 & 0.38 & 8 & 5 & .45 & .44 & 0.77 & 9 & 2 & $0.7:$ \\
\hline 疄 & in & 0.43 & 0.37 & .42 & 0.41 & - & 0.72 & 0.59 & 0.66 & 1.12 & 0.98 & 1.09 & 1.0 \\
\hline [ii]. & I 綃 & $( \pm)$ & $1+1$ & $(+)$ & & $( \pm)$ & $( \pm)$ & $( \pm i$ & & $( \pm)$ & $( \pm)$ & $( \pm)$ & \\
\hline sis & 119 & $(t+)$ & $(t+)$ & $(+)$ & & $1+t$ & $(+t)$ & $(t+1$ & & $(++)$ & $(t+)$ & $(t+1)$ & \\
\hline & 脑火外徑 $(\mu)$ & 121 & 103 & - & $10 x$ & 123 & 125 & 137 & 128 & 177 & 168 & 171 & 17 \\
\hline & 内 谐 & (大) & 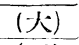 & (人) & & (大) & (大) & (大) & & (大) & 以 & (大) & \\
\hline & 精 租 細 & (H) & $(t+$ & $1+t$ & & (H) & (H) & (H) & & $(+\#$ & $(+\#)$ & (itt) & \\
\hline 沂 & 精母 細 & (世) & ( & $\left(H^{\prime}\right.$ & & (it+) & $(\mathrm{H})$ & $(\mathrm{HH})$ & & $(+i t)$ & $(1+4)$ & $(t+t)$ & \\
\hline & 精 艮 細 胞 & (H) & $(t+)$ & $(t+)$ & & $(t+1)$ & $(H)$ & (\#) & & $(\mathrm{HW})$ & $(\mathrm{HtI})$ & $(t+t)$ & \\
\hline & 子 & $(+)$ & $( \pm)$ & $(-)$ & & $( \pm)$ & $(+)$ & $1+1$ & & $(+H)$ & $(+t)$ & $(t+1)$ & \\
\hline & 议火外徑 $(\mu)$ & 390 & 338 & 390 & . & 468 & 624 & 494 & 29 & 832 & $5+6$ & 481 & 6 \\
\hline & 充寒性 ノモノ & $(+)$ & $( \pm)$ & $1+1$ & & $( \pm)$ & $(+)$ & \pm & & $( \pm)$ & $( \pm)$ & $( \pm)$ & \\
\hline 㨨䒜 & 腔形戌初期ノモノ & $(+)$ & $(H)$ & $(t+)$ & & $(t+)$ & $1+1$ & $(+)$ & & $( \pm)$ & $( \pm)$ & $(+)$ & \\
\hline & 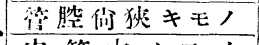 & $(+)$ & $(+t)$ & $(+)$ & & $(+1)$ & $(+)$ & $(+1$ & & $(1+)$ & $(+1)$ & $( \pm)$ & \\
\hline & 占等大ノモノ & (H+H) & $(H+1)$ & $(+\#)$ & & $(+)$ & $(t+)$ & (H) & & $(+)$ & $(+1)$ & $(+)$ & \\
\hline 腺 & 㢈 $\neq$ & (HI) & $(t+)$ & $(t+)$ & & (HI) & $(H)$ & (H) & & $(+\#)$ & $(+\#)$ & $(+\#)$ & \\
\hline & 分泌物キ容ルルモノ & (\#) & $(++)$ & $(t+1$ & & $(t+)$ & $(\mathrm{H})$ & $(\mathrm{H+1}$ & & $(\mathrm{HH})$ & $(+n)$ & $(t+t)$ & \\
\hline & |分岐著シキモ， & $(H+)$ & $(t+)$ & $(t+)$ & & $(H+1)$ & (H) & (\#) & & $(\overline{(H t)}$ & $(+H)$ & $(+\#)$ & \\
\hline
\end{tabular}


第 2 表 腦下更體前葉「エキス」キ注射セシ例

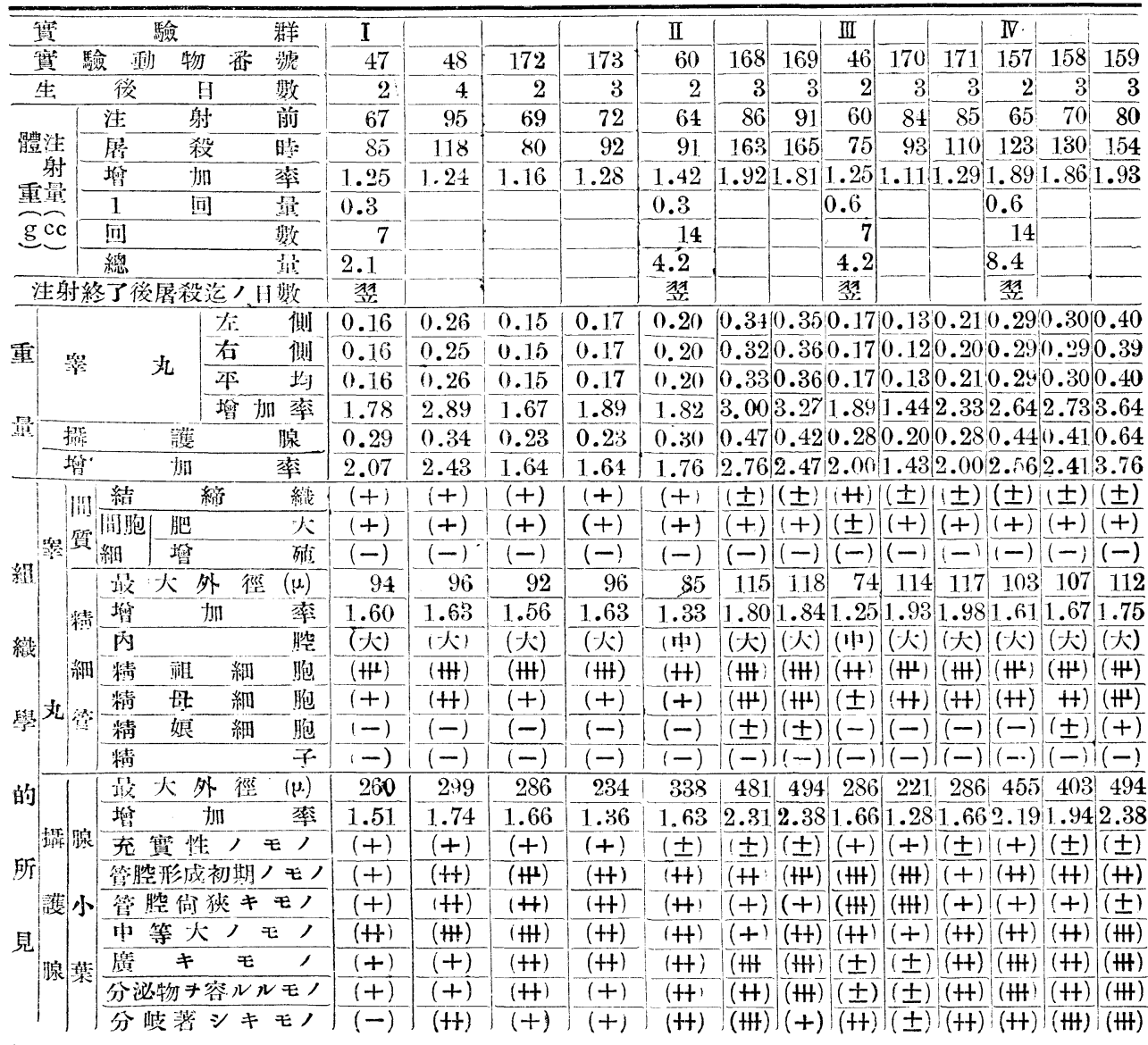

\begin{tabular}{|c|c|c|c|c|c|c|c|c|c|c|c|c|c|}
\hline 實 & 馬 & & 賠前 & $\nabla$ & & & VI & & & & VII & VIII & \\
\hline & 驗 㗢 & 物 & 番 號 & 139 & 140 & 141. & 103 & 104 & 112 & 113 & $\begin{array}{ll}131 & 132\end{array}$ & $\begin{array}{lll}138 & 135\end{array}$ & 136 \\
\hline 生 & E後 & H & 教 & 3 & 3 & 3 & 3 & 3 & 2 & 2 & 3 & 3 & \\
\hline & 注 & 射 & 前 & 75 & 85 & 83 & 85 & 80 & 75 & 65 & \begin{tabular}{l|l|}
78 & 75 \\
\end{tabular} & $90 \quad 75$ & 65 \\
\hline 洼 & 屠 & 殺 & 時 & 133 & 152 & 142 & 115 & 105 & 118 & 116 & $\begin{array}{lll}146 & 145\end{array}$ & $\begin{array}{l}126 \\
188\end{array}$ & 182 \\
\hline & 堆 & 加 & 率 & 1.77 & 1.79 & 1.71 & 1.35 & 1.31 & 1.57 & 1.78 & 1.871 .93 & 1.402 .51 & 2.80 \\
\hline I & 1 & 回 & it & 0.3 & & & 0.3 & & & & 0.6 & 0.6 & \\
\hline g c c s & 回 & & 教 & 7 & & & 14 & & & & 7 & 14 & \\
\hline & 總 & & 量 & 2.1 & & & 4.2 & & & & 4.2 & 8.4 & \\
\hline & 射終了後目 & 殺殺范 & 级口數 & 7 & & & 7 & & & & 7 & 7 & \\
\hline & & & 側 & 0.22 & 0.24 & 0.19 & 0.23 & 0.25 & 0.20 & 0.19 & $0.20 \mid 0.17$ & 0.140 .42 & 0.36 \\
\hline 電 & 1 & & 側 & 0.21 & 0.24 & .20 & 0.24 & 0.25 & 0.20 & 0.19 & 0.210 .22 & 0.140 .43 & 0.35 \\
\hline & & & $\pm=1$ & 0.22 & $0.2 t$ & 0.20 & 0.24 & 0.25 & 0.20 & 0.19 & 0.210 .20 & 0.140 .43 & 0.3 \\
\hline & & & 增加率 & 2.00 & 2.18 & 1.82 & 2.00 & 2.08 & 1.67 & 1.58 & 1.911 .82 & $1 . 2 7 \longdiv { 3 . 5 0 }$ & 3.0 \\
\hline 暴 & 潞 & 護 & 腺 & 0.26 & 0.36 & 0.25 & 0.35 & 0.37 & 0.38 & 0.39 & 0.290 .35 & 0.280 .71 & 0.6 \\
\hline & 管 & 加 & 率 & 1.53 & 2.12 & 1.47 & 1.84 & 1.95 & 2.00 & 2.05 & \begin{tabular}{|l|l|}
1.75 & 2.0
\end{tabular} & 1.653 .74 & 3. \\
\hline
\end{tabular}




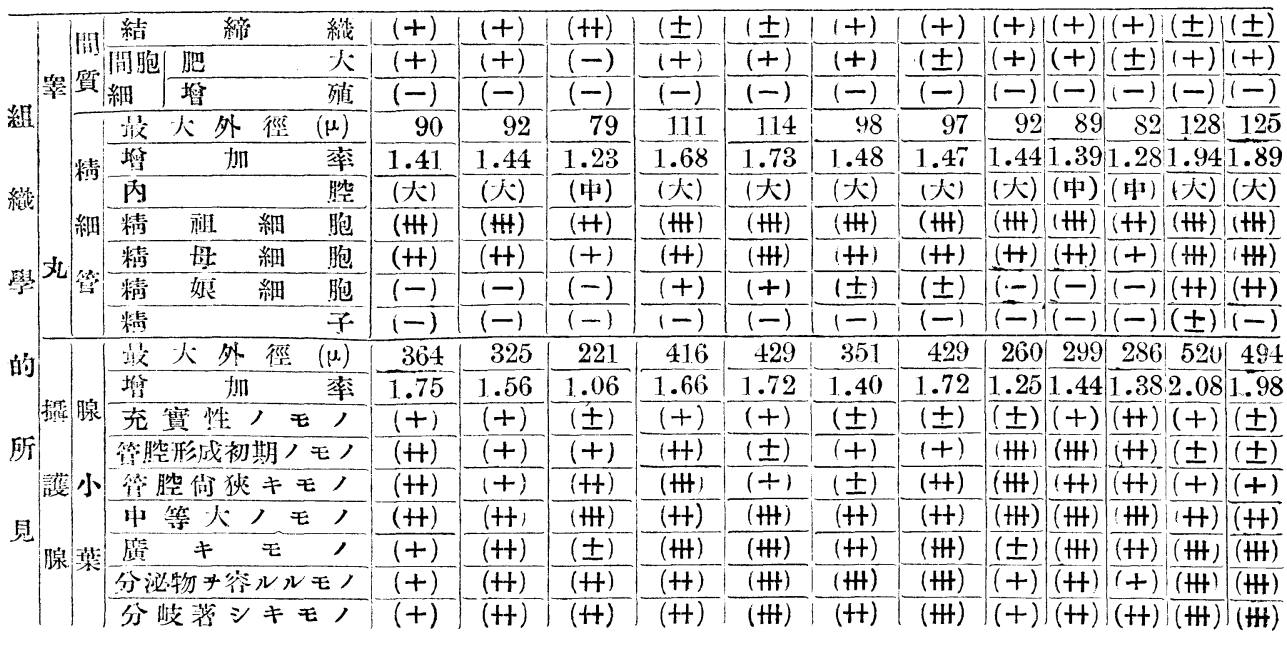

整 驗 群 $\mid$ VIII

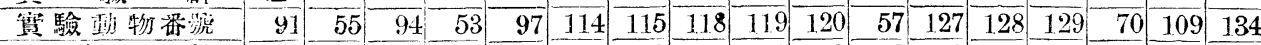

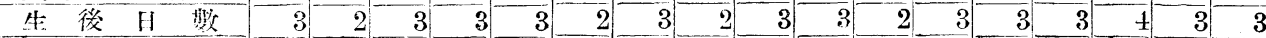

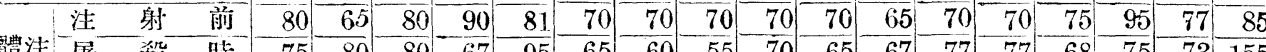

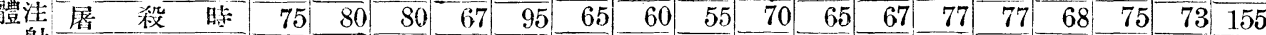

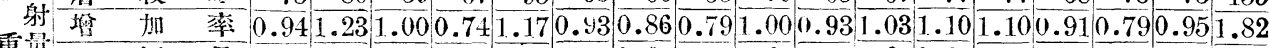

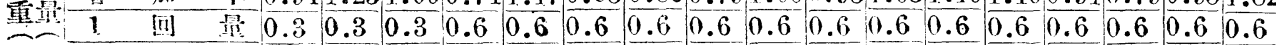

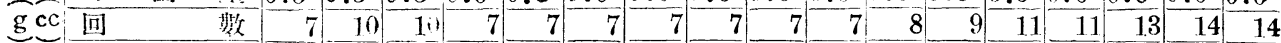

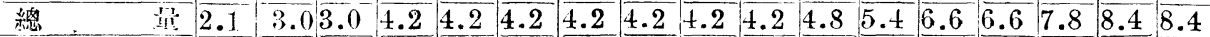

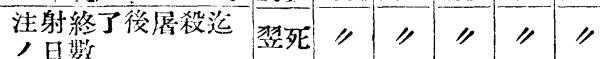

T后 侧 $0.140 .150 .170 .160 .13|0.17| 0.12|0.120 .15| 0.120 .17|0.180 .150 .20| 0.29 \mid 0.240 .37$

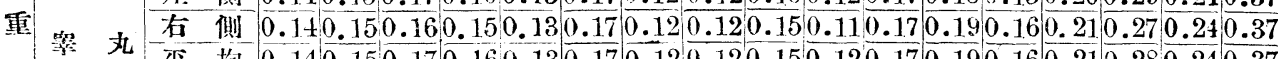

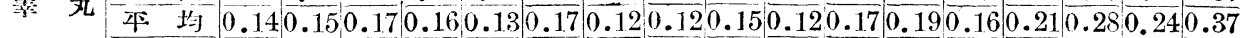
篔加率 $1.56 \quad 1.781 .441 .89$ 1.33 1.331 .671 .33

$2 . 1 8 \longdiv { 3 . 3 6 }$

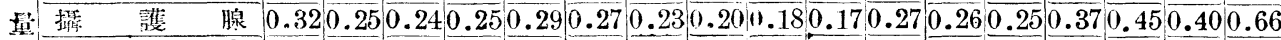

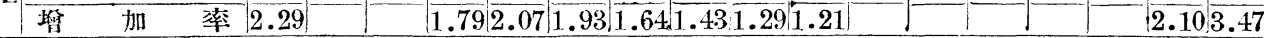

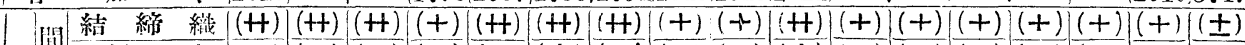
椞 191 胞 萌

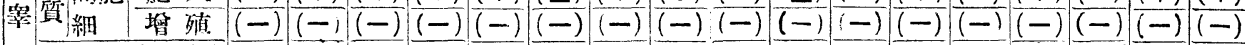

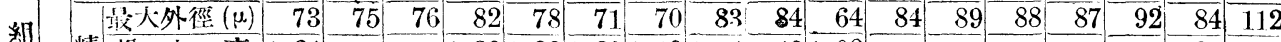
精塯 加 率 1.24 - 1.391 .321 .201 .191 .141 .421 .08 - -1.311 .75$ 队 望 (中) (中) (中) (中) (中) (中) (中) (中) (中) (小) (中) (中) (中) (中) (大) (中) (大)

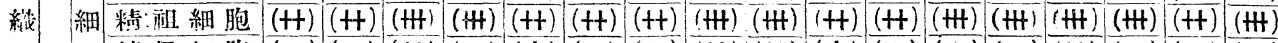

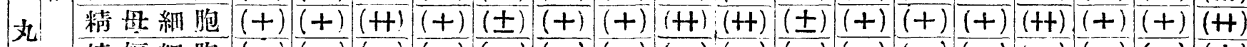

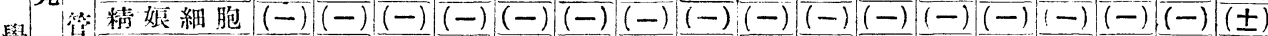

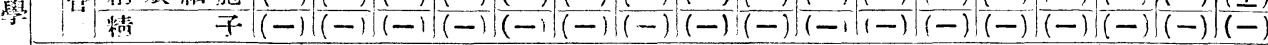

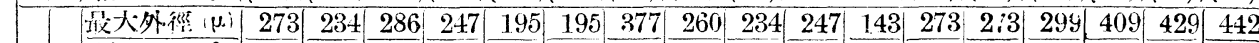

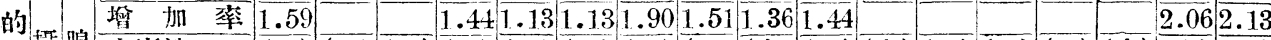

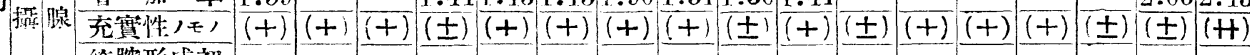

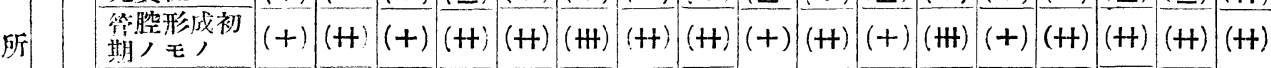

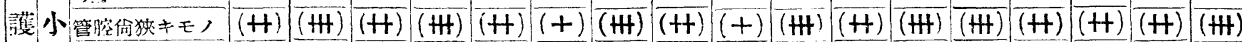

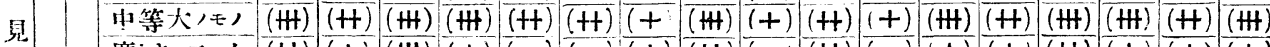

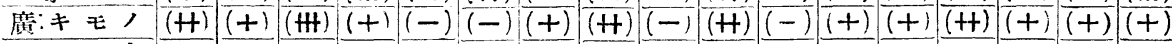

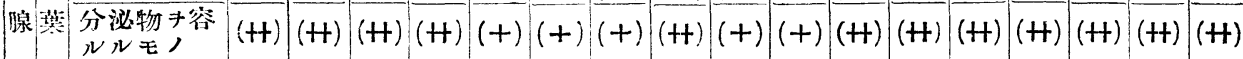
分蚑蕃シキモ, $\overline{(+)}|\overline{( \pm)} \overline{(+t)} \overline{(+)} \overline{(-)} \overline{(-)} \overline{(-)}| \overline{(+)}|\overline{( \pm)}| \overline{(+)}|\overline{(-)}| \overline{(+)}|\overline{(+t)}| \overline{(+)}|\overline{(+)} \overline{( \pm)}| \overline{( \pm)}$ 
第 2 表二示スガ如ク，先ヅ所定注射終了後竝日屠殺七シモノフ見ルニ，1回量 $0.3 \operatorname{cc} 71$ 週間

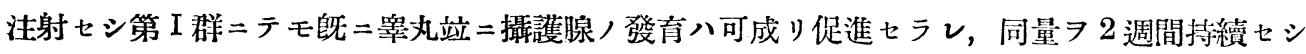
第 II 群ニハ更二著明トナレリ. 次 $=1$ 回量 $70.6 \mathrm{cc}$ 宛注射シ 1 週間反復セシ第群ニテハ 1 回量 $0.3 \mathrm{cc} \ni \cdot 1$ 週間注射セシ第 I 群二比シ更二著明ナルモ, 1 回量 $0.3 \mathrm{cc} 72$ 週間持續セシ第且群二 比スレバ，注射總量ハ何レモ4.2cc ニシテ同量ナルモ，稍と之二劣レルガ如シ．而シテ 1 回量 $0.6 \mathrm{cc} \ni 2$ 週間持續セシ第 $\mathbb{\nabla}$ 群ニテハ最モ著明ナリ。

以上ハ注射終了後翌日屠殺セシモノニシテ，此ノ場合最終洼射/效力ハ未ダ充分二發垉七ラ

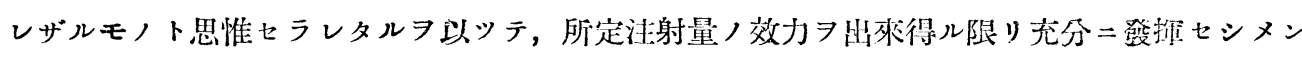
ガタメ，以上ノ各群二於ケルト同樣=實驗シ，唯注射終了後 7 日目 $=$ 屠秌七ル第 $\nabla$ 一四群二ア

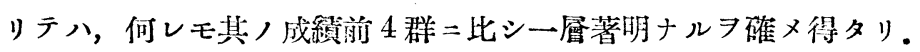

\section{第 3 項 本節ノ概括及ビ考察}

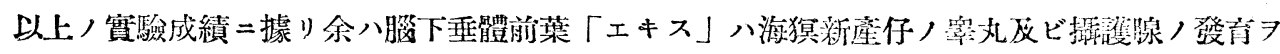
著朋二促進スルモノナルラ推知シ得タリ。

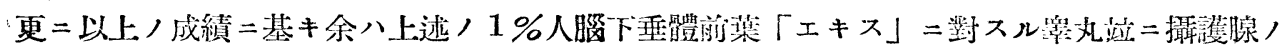
反應习檢查シ，先人ノ成績卜比較考察七り。

先ジ睪丸二就テ見ル二重量增加率ハ一般二著シク大ニシテ其ノ最大ナルモノハ 3.64 二達ス。

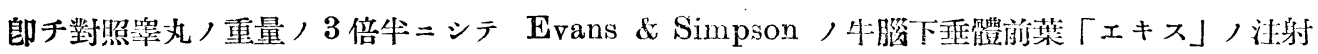

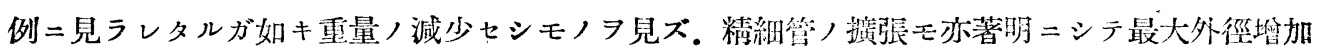
率ノ最大ナルモノ八1.98=達シ對照例ノ略 22 倍ヨ示セリ。而シテ造精機轉ノ進展 フ見ルニ, 反應ノ程度二從七各時期ノ精細胞ノ出現尹見ルモノナレドモ，最モ著明ナルモノニ於テスラ Voss u. Loewe, Belawenetz 等, 言へルガ如キ定型的ナル精子ノ發生フ芫ルニ至ラザリキ。

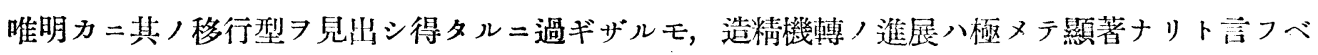
シ.間質ニテハ間細胞,肥大八大多數二見ラレタルモ, 國重, Steinach u. Kun等, 如キ其， 增殖セル例 抑制セラレタル例ラ見タル事ナシ。

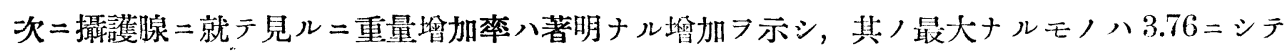
對照例, 約 3 倍牛トナレリ。腺小葉最大外徑增加率ハ一般二著シク大トナリ, 其ノ最大ナルモ ノ 2.38 =薘シ對照例ノ約 2 倍卅トナレリ。

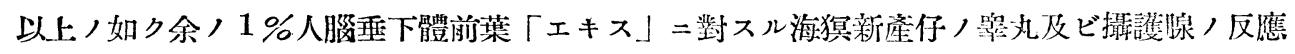

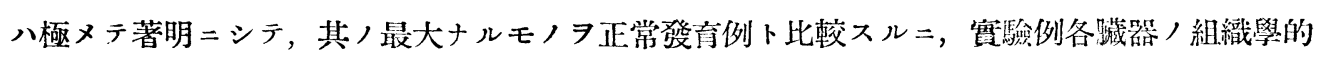
所見八何レモ大約生後40日，例二見ラル、ガ如キ所見 7 呈七り。

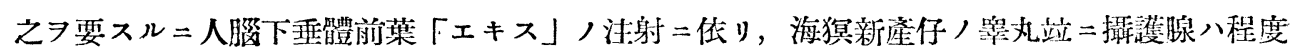
ノ差ハアレドモ, 兩者共二夫等,發育八著シク促進セラレ, 其ノ著明ナルモノ八大約生後 40 日 
ノ例ニ相常シ, 生長日數ヨリえヨ見ル時ハ約17日ダケノ促進ヨ示スモノト言フベシ。

因i二該「エキス」ノ作用 7 注射量卜注射期間卜ノ關係ヨリ示セバ次ノ如シ.

1. 1 回量 $0.3 \mathrm{cc} 71$ 週間注射七ル例二モ可成り著明二該組織ノ發直促進認メラル.

2. 1 回量 $70.6 \mathrm{ce}=$ 增加シテ注射スル時八更二其ノ發育著明ナリ.

3 。注:射期間 72 週間二延長スル時ハ 1 回量 $0.3 \mathrm{ec}$ 用フルモ藷明二其ノ發育促進七ラレ, 該 量 $70.6 \mathrm{ec}=$ 增㞦スル時八其ノ結果更二著明ナリ.

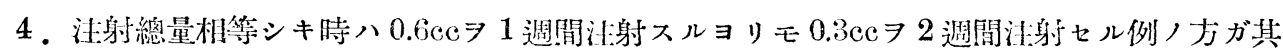
ノ作用顯著ナリ。

\section{第 3 節 腦下垂體後葉「エキス」/雄性海溟新産仔生殖器ノ發育二及ボス影響}

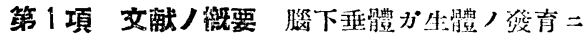
重大ナル關係キ有スルモノナルハ, 既二㙨多ノ臨 牃的站二賽驗的研究二依り周知ノ事賽ナルモ, 近 時內分泌學ノ莸シキ進步二体七臘下垂體前菜卜坐:

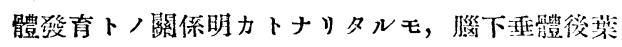

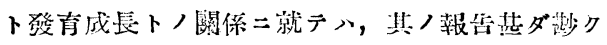
Romeis (1913)，Krizenecky (1924) 等入们 $レ モ$ 㷋

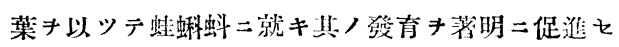

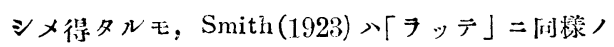

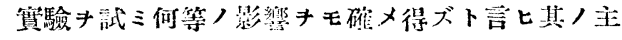
涱互二相反スルモノノ如シ。

一般二後菜卜生列腺卜/關係二就テノ報告入誠 二家々タルモノニシテ, 就中後葉卜雄性生殖器卜

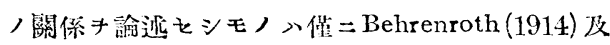
ピ大西（1931）八報告アルニ過ギブ, 此等ハ共二

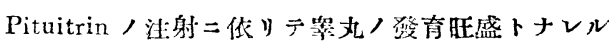
キ見タリト芳フ。

\section{第2 項 實 驗成 綪}

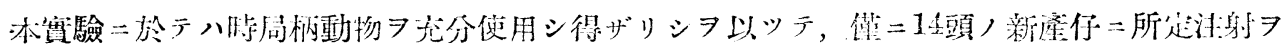
施シ其終了後7日月二展㸚鏡檢七り。

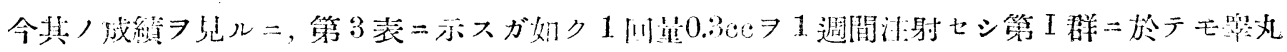

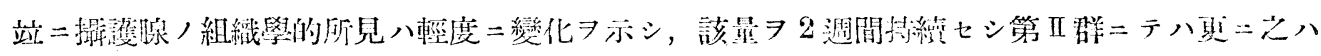
著明トナリ可成り發高入促進七ラル。

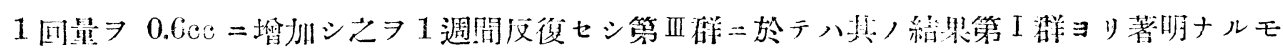

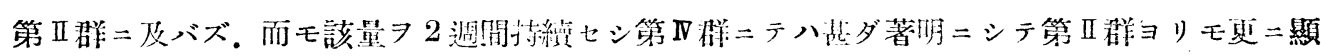
著トナレリ。

\section{第 3 項 本節ノ概括及ビ教察}

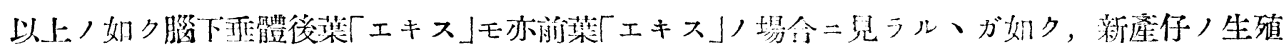
器發方习促進七シムルモノナリ。

睪丸ニテハ重量增加率八本群二テモ亦著シク大トナリ，其ノ最大ナルモノハ 1.83 オ示シ對照 例ノ略飞 2 倍二近クナレリ. 精細管最大外徑增加率八最大ナルモノ 1.42 二シテ對照例ノ約 1 倍

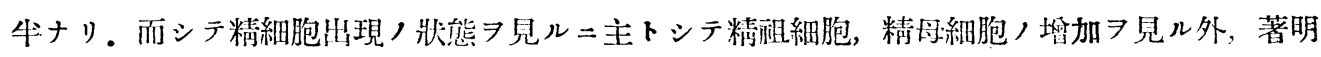

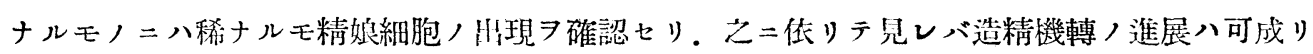


第 3 表 腦下垂體後烡 $[\boldsymbol{x} キ>」 \neq$ 注射セシ例

\begin{tabular}{|c|c|c|c|c|c|c|c|c|c|c|c|c|c|c|c|c|}
\hline 賔 & & 群 & I & & II & & & & & III & & & & & IV & \\
\hline 䨘 & 驗 & 䣦 物 番 蹠 & 200 & 201 & 162 & 163 & 164 & 207 & 208 & 154 & 155 & 156 & 180 & 187 & 190 & 191 \\
\hline 生 & & 形 & 3 & 3 & 3 & 3 & 3 & 2 & 2 & 4 & 4 & 4 & 3 & 4 & 4 & - \\
\hline & 注 & 射 & 86 & 85 & 80 & 80 & 80 & 76 & 72 & 95 & 95 & 98 & 85 & 96 & 97 & $\overline{98}$ \\
\hline $\bar{g}$ & & 殺 & 130 & 144 & 160 & 170 & 167 & 159 & 146 & 140 & 135 & 160 & 152 & 157 & 176 & 185 \\
\hline & 咕 & 率 & 1.53 & $1.6^{9}$ & 2.00 & 2.10 & 2.09 & 2.09 & 2.03 & 1.47 & 1.42 & 1.63 & 1.79 & 1.64 & 1.81 & 1.87 \\
\hline & 1 & is & 0.3 & & 0.3 & & & & & 0.6 & & & & & 0.6 & \\
\hline 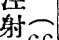 & [1 & 数 & 7 & & 14 & & & & & 7 & & & & & 14 & \\
\hline ecc & & 量 & 2.1 & & 4.2 & & & & & 4.2 & & & & & 8.4 & \\
\hline 注身 & 射終 & 了後展殺沦/日数 & 7 & & 7 & & & & & 7 & & & & & 7 & \\
\hline & & $t_{1}:$ & 0.12 & 14 & .20 & 0.210 & $\overline{4}$ & 0.18 & 70 & 0.120 & 11 & 40 & 161 & 0.14 & .200 & .22 \\
\hline & & 側 & 0.12 & 0.14 & 0.19 & 0.21 & 0. & .17 & 170 & 0.120 & 0 & 0 & 0.160 & 0.14 & .20 & .22 \\
\hline & 莩 & 均 & 0.12 & 0.14 & 0.20 & 0.219 & 0.1 & 1 & 0.170 & 0.12 & .0 & 0.14 & .160 & .1 & .20 & .22 \\
\hline & & 細加率 & 1.09 & 1.27 & 1.67 & 1.75 & 1.58 & 1.50 & 1.421 & 1.09 & 1.00 & 1.27 & 1.45 & 1.27 & 1.671 & 1.83 \\
\hline$g$ & 掫 & 腺 & 0.16 & 0.17 & 0.28 & $\overline{3.29}$ & 9.26 & 1.24 & 0.230 & .180 & 0.17 & 0.200 & 0.22 & 0.18 & 0.260 & .28 \\
\hline & 增 & 紊 & 0.94 & 1.00 & 1.47 & 1.58 & 1.37 & 1.26 & 1.211 & 1.061 & 1.00 & 1.18 & 1.29 & 1.06 & 1.371 & 1.47 \\
\hline & & 絬 & $(t+)$ & $(t+)$ & $(+)$ & $(+)$ & $(+)$ & +1 & +1 & $+t)$ & $(\mathrm{H})$ & $(t+)$ & + & + & +1 & $(+1)$ \\
\hline & & 間胞 把 & $(-)$ & \pm & +1 & $(+)$ & $(+)$ & $(+)$ & $( \pm)$ & $\pm)$ & $(-)$ & \pm & + & +1 & +1 & $(+)$ \\
\hline & & 細墖 & $(-)$ & $(-)$ & -1 & $(-)$ & $(-)$ & $(-)$ & $(-)$ & $(-)$ & $(-)$ & $1-$ & $(-)$ & -1 & -1 & $(-)$ \\
\hline & & 最大外徑 $(\mu)$ & 76 & 78 & 87 & 88 & 85 & 83 & 86 & 78 & 76 & 79 & 81 & 80 & 93. & 94 \\
\hline & 精 & 懈 & 1.19 & 1.22 & 1.32 & 1.33 & 1.29 & 1.26 & 1.301 & 1.22 & 1.19 & 1.23 & 1.27 & 1.25 & 1.40 & 1.42 \\
\hline 綶 & & 內 & (山) & (1) & (4) & (口) & (1) & (1) & (中) & (中) & (中) & (1) & $(1 \mathrm{l})$ & $(n)$ & (大) & (大) \\
\hline & 細 & 精坥，細 & $(t+)$ & $(+t)$ & (姍) & $(t+1)$ & $(\mathrm{HH})$ & (H) & (H) & $(t+)$ & $(t+)$ & $(\mathrm{H})$ & (Hit) & $(\mathrm{HI})$ & (t+t) & $(\mathrm{HI})$ \\
\hline & & 精 母 細 胞 & $(-)$ & $( \pm)$ & (H) & $(+t)$ & $(t+)$ & +1 & $(+t)$ & $\pm)$ & \pm & \pm & $(+)$ & \pm & $(t+)$ & $(t+)$ \\
\hline & & 精 娘 細 胞 & $(-)$ & $(-)$ & $(-)$ & $( \pm)$ & $(-)$ & $(-)$ & $(-)$ & $-)$ & $(-)$ & -1 & -1 & $(-)$ & $( \pm)$ & $(+)$ \\
\hline & & 7 & $(-)$ & $(-)$ & $(-)$ & $(-1)$ & $(-1$ & $(-1)$ & $(-1)$ & $(-1)$ & & -11 & $(-1)$ & $(-1)$ & $(-\infty)$ & $(-1)$ \\
\hline & & 最大外得 $(\mu)$ & 195 & 234 & 273 & 299 & 234 & 200 & 273 & 247 & 145 & 145 & 273 & 284 & 390 & 416 \\
\hline & & 加 & 0.94 & 1.13 & 1.09 & 1.20 & 0.94 & 1.04 & 1.091 & 1.19 & 0.94 & $\overline{0.94}]$ & 1.31 & 1.13 & 1.56 & 1.66 \\
\hline & & 充寒性 ノモノ & $( \pm)$ & $(+)$ & $( \pm)$ & $(+)$ & \pm & $(+)$ & \pm & $\pm)$ & $(+)$ & \pm & + & $(+)$ & $(+)$ & $( \pm)$ \\
\hline 所 & & 悬嘋成形初期ノモノ & $(+)$ & $(t+)$ & $(+)$ & $(t+)$ & $(+)$ & $(t+)$ & $(+)$ & $(t+)$ & $(+)$ & $(+)$ & $(+)$ & $(t+)$ & $(t+)$ & $(+)$ \\
\hline 護 & 小 & 管腔何狄キモノ & $(+t)$ & $(t+)$ & $(+t)$ & $(+)$ & $(+)$ & (H) & $(+)$ & $(+)$ & $(t+)$ & $(t+)$ & $(+t)$ & $(+)$ & $(+)$ & $( \pm)$ \\
\hline 見 & & 中等大， & $(t+)$ & $(t+)$ & (H) & (H) & $(\mathrm{H})$ & $(++)$ & (H) & $(+t)$ & $(+t)$ & $(t+)$ & (H) & $(t+)$ & $(\mathrm{Ht})$ & $\overline{(t+1)}$ \\
\hline 腺 & & $\neq \quad$ 玉 & $( \pm)$ & $(+)$ & $(t+)$ & $(\mathrm{H})$ & $(+)$ & $( \pm)$ & $(+)$ & $(+)$ & $( \pm)$ & $( \pm)$ & $(+)$ & $(t+)$ & $(\mathrm{Ht})$ & $(\mathrm{Ht})$ \\
\hline & & 分泌物キ容ルルモノ & $(+)$ & $(+)$ & $(+)$ & $(\mathrm{tH})$ & $(+)$ & $(+)$ & $T+1$ & $(+)$ & $(+)$ & $(+)$ & $(+)$ & $(+)$ & $(+t)$ & $(\mathrm{tHt})$ \\
\hline & & 分忮蓄シキモノ & $( \pm)$ & $( \pm)$ & $(\mathrm{H})$ & $\mid \overline{(+t)}$ & $( \pm)$ & $(+)$ & $(t+)$ & $(+)$ & $( \pm)$ & (土) & $(\mathrm{tt})$ & $(+)$ & (tH) & $(\mathrm{tt})$ \\
\hline
\end{tabular}

著明ナリト言ハザル可カラズ，即チ Behrenroth 及ビ大西ガ Pituitrin，注射例二見タルガ 如ク性早期成熟ヨ惹起スルモ，ト言フベシ。侗閒質ニテハ大多數二間細胞，肥大ア認メタルモ 其ノ增殖ヨ見タル事ナシ.

攝護腺二就テ見ル二重量增加率ノ鼠大ナルモノハ1.47 =シテ對照例ノ約 1 倍坐ナリ．而シテ 腺小葉最大外徑增加率八其ノ最大ナルモノ1.66 ニシテ對照例ノ約 1 倍本ナリ。

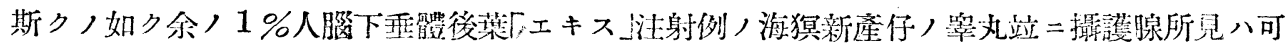

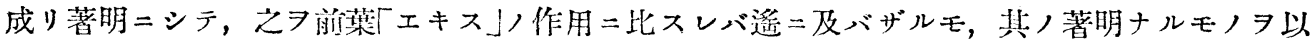
ツテ正常發育例ノ夫レト比較スレバ，雨者共二大體ニ於ラ生後30日ノモノニ相常シ，發育促進 ノ程度ハ可成り著明ナリト言フベシ。郎チ腦下垂體後葉八前葉二比スレバ其ノ作用弱キ事明カ ナルモ, Aschner, Trendelenburg, Kraus 等ノ言へルガ如ク生殖器ノ發育二門關係ナルモ， 二非ズ，朋カ二其，發育习促進七シムルモノト解シ大過無キガ如シ。

最後ニ余ノ $1 \%$ 人腦下垂體後菜「エキス」ノ作用 7 注射量站=注射期間トノ關係ヨリ示七バ次 
ノ如シ。

1. 1 回量 $0.3 \mathrm{cc} \Rightarrow 1$ 週間汒射スルモ生殖腺, 發育促進七ラル。

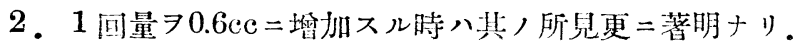

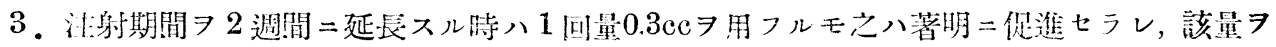
$0.6 \mathrm{ec}$ 二䇥加スル時八更二著明トナレリ。

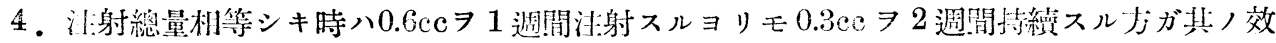

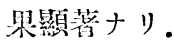

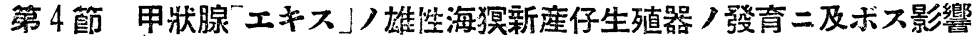

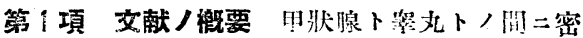

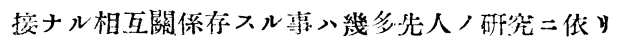
明カナリ。然レドモ詳細ナル㸠項二至りテ入或入 一致シ，或入然ラズシテ必ブシモ未ダ一定セズ，

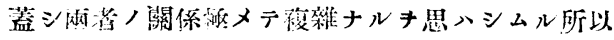
ナท.

先ヅ臨床的二該腺奖虫タル Basedow氏病二於タ ル凛好變化二就テ貝ル Chrustalew (1913)， Kraus (1924) 等八變化ナシト远べ, 加藤 (1920) ハ初 期萎縮子見タリト言フ。其，他粘液水喠，Kretin

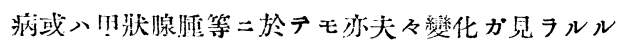
モノノ如ク，Marchand (1906), Sternberg (1920)

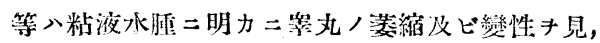
Diamontopolus (1921) B Bern /兒童二就テ調查シ

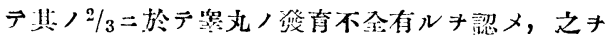

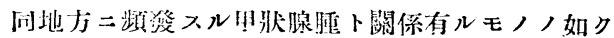

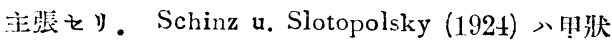

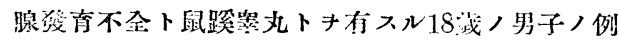

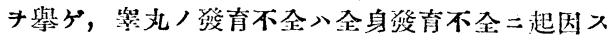
ルモノナラント說クリ。

次二賽驗的研究ノ主ナルモノキ見ル $=$, Eiselsberg (1901), Lanz (1904), IIofmeister (1921) 等 八狀腺剔出二依ル生磌腺萎縮キ訅载シタルモ， Evans \& Long (1921）八早狀腺剔出後㕠情期八出

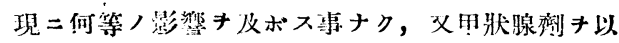

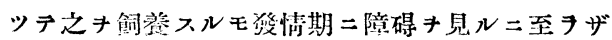
リシ事キ㝘へリ。 Remotti (1926) 八田状腺剠飼荃

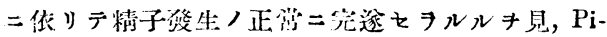

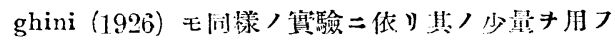

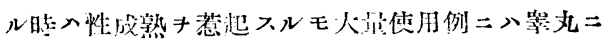

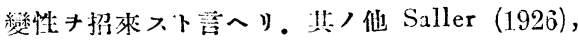

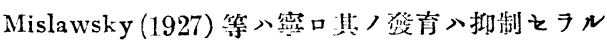
卜主㬨せリ。

Belawenetz (1928) 八 Thyreokrinキ以ツテ「尹,

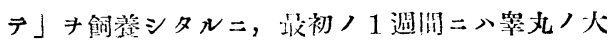
サ，重号入勿論其八組䋊像等二何等ノ變化キモ見

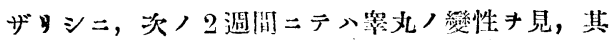

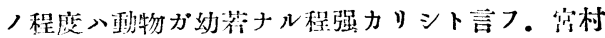

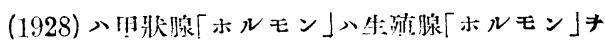

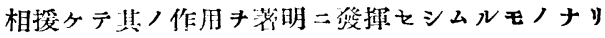

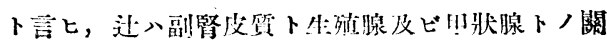

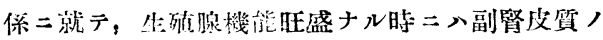
分泌キ要求スルモノニシテ，副腎皮貿機能之二及 バザル時八目状腺 ハ代傥的二其ノ機能キ元進セシ ムルモノナリ卜詨明をタ。 Döderlein(1930) 八海 猽二留狀㟫末キ內服セシメ其ノ生殖能力キ檢をシ

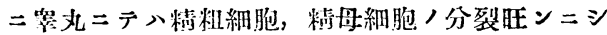
テ形您學的二八充分二機能入保持セフレタルモ， 雌性期物キシテ受眙セシメ得ザリシキ以ツテ，生 物學的二ハ必ズシモ健全ナアズトシ，甲狀腺/機 能光進二依ル生殖腺ノ機能低下, 原因八，甲狀腺 ノ生殖腺二對スル拄接ノ拮抗作用二依ルモノニ非 ズシテ葢口可溶性脂肪物質キ会份セル血液ノ過剩

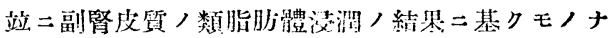
タント䓂ヘリ。

\section{第2項 實 騷 成 績}

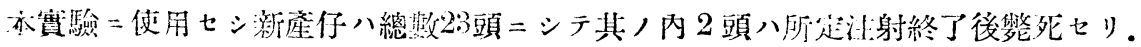




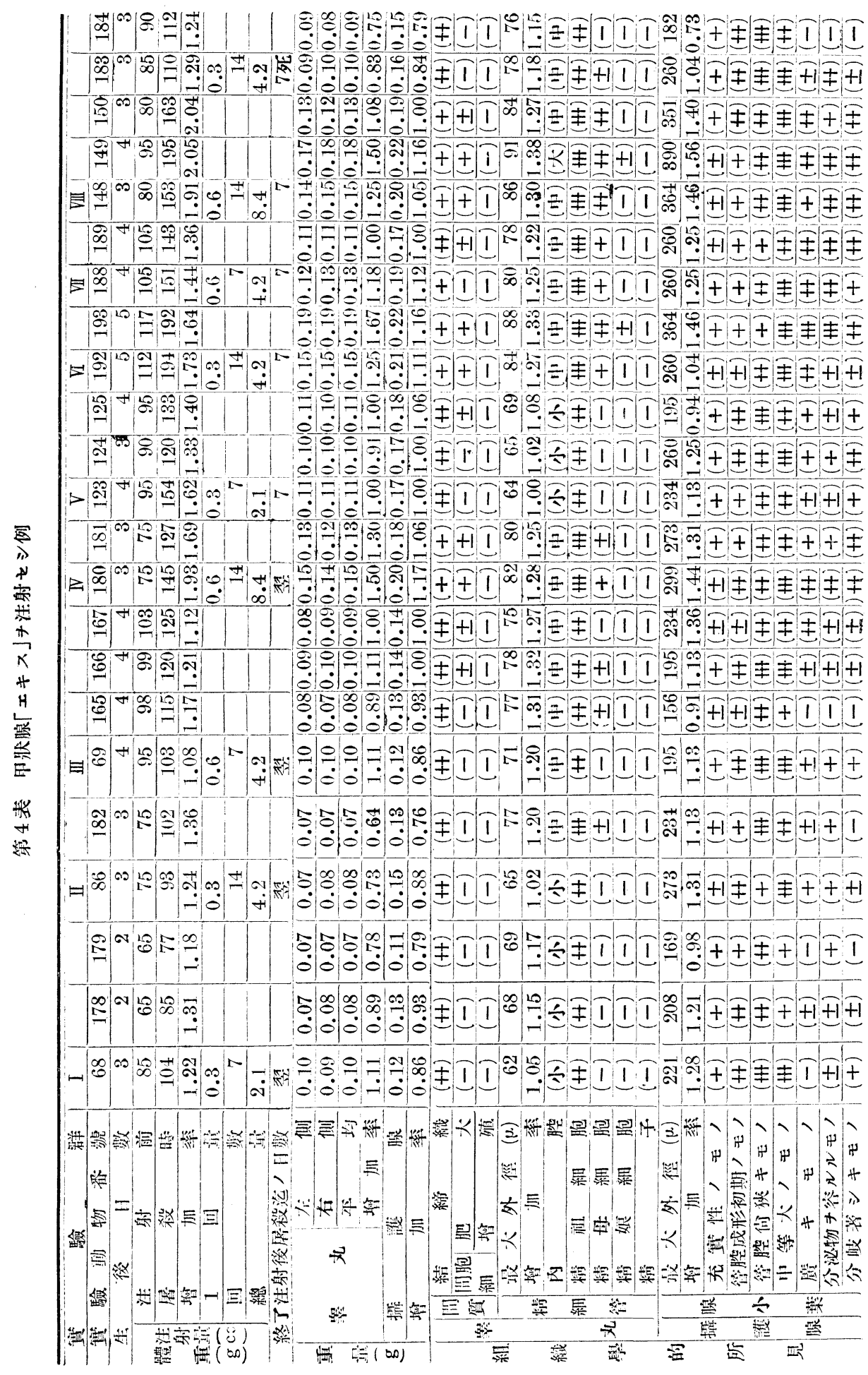




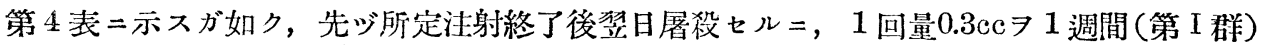
及ビ 2 週間(第I群)沬射シタルモノニハ，睪丸立二攝護腺ノ重量八何レモ對照例=及バザレド モ, 組織學的ニ八明カニ變化ヨ示シ兩群共二輕微乍ラ發育八促進セラレタリ。 1 回量0.6ec 71 週閒注射七シ第正群ニテハ重量ハ何レモ對照例ト大美ナク組織學的變化モ秒に著明トナレリ。 而シテ該量 72 週間持續セシ第 $\mathbb{N}$ 群ニテハ重量ハ輕度二增扣シ，組織學的二八變化更二著明卜 ナリ兴等ノ發育八可成り促進七ラレタリ。

次二所定注射終了後 7 日目二屠殺セル例ニテハ其ノ所見们レこ前 4 群二比シ著明ニシテ， 1

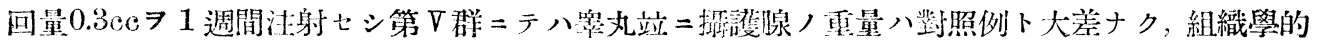

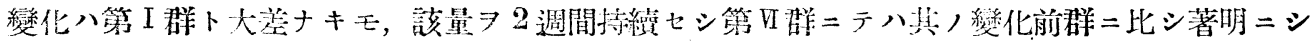

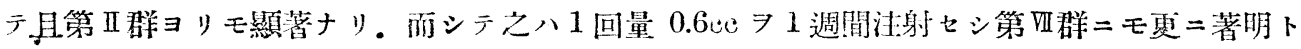

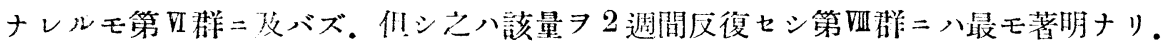

\section{苇 3 項 本笁ノ概括及ビ考察}

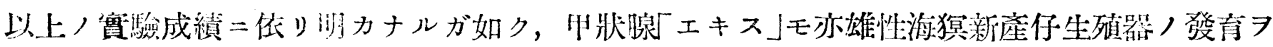

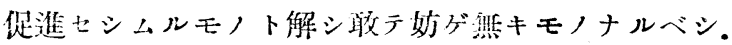

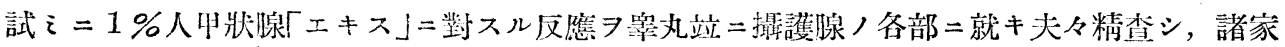

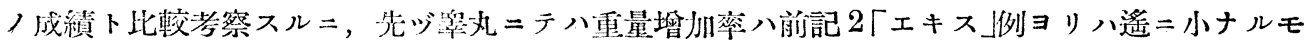

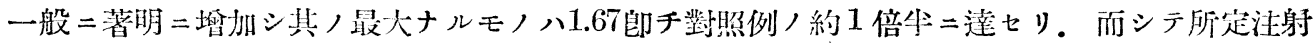

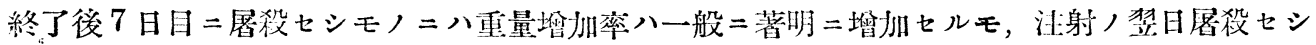
モノニハ却ツテ其ノ減少セルモノラ見タルハ，屠殺時期ノ少早ナリシタメ所定注射量/效力ガ 末ダ充分二發揮セラレザリシニ因ルモノナルベシ。精細管最大外徑增加受八最大ナルモノ 1.38

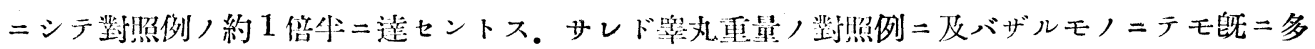

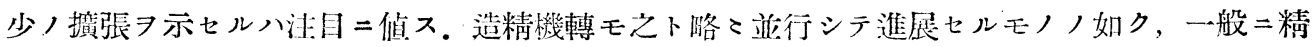

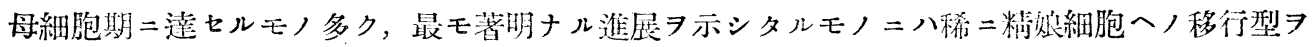
見タルモノ有りテ其ノ進展ハ可成り著明ナリト言フベシ。

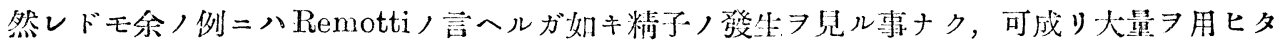
ルモPighini，見タルガ如キ變性ヨ惹赸七シモノナシ。更二 Saller, Mislawsky ノ言へルガ如 キ排制セラレタルモノフ見ル能ハザリキ。

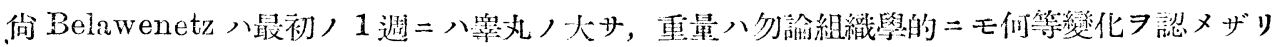

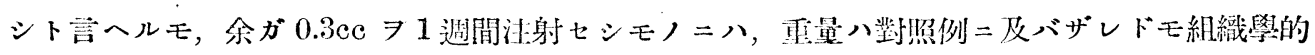

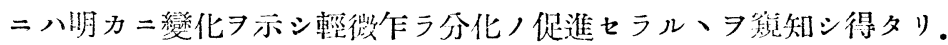

間質ニテハ明カ二間細胞,肥大七ルモノフ見タルモ，之八極メテ稀ニシテ僅二精細管，變化 ガ著明ナリシモノニ於テノミ芫ラレタリ。然レドモ其ノ塯殖フ見タル事ナシ。

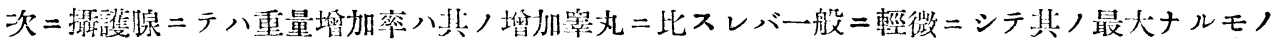


モ1.17ヨ示ャルニ過ギズ，然レドモ腺小葉最大外徑增加率八一般二大ニシテ其ノ最大ナルモノ ハ1.56ᄏ示シ對照例ノ約 1 倍里トナレリ。

以上ノ如ク余， $1 \%$ 人妇狀腺「エキス」ヨ以ッテセル海猽新產仔，罳丸端二攝護腺，反應八可 成り著明ニシテ，其ノ著シキモノフ正常發育例ト此較七シニ何レモ大體ニ於テ生後30日ノモノ ニ相當シ，生後 27 日ノモノニ比スレバ稍に之ヨ凌駕セリ。

該「エス」ノ作用ヨ注射量ト注射期閒トノ關係ヨリ見ル二次ノ如シ.

1. 1 回量 $0.3 \mathrm{cc} \ni 1$ 週間注射スルモ睪丸及ビ攝護腺, 發育 7 促進セシメ得.

2 . 該量 72 週間持續スル時ハ之八可成り著明トナル。

3. 1 回量 $0.6 \mathrm{cc}=$ 增加スル時ハ 1 週間注射スルモ可成り著シクシテ更ニえ 2 週間持續 スル時ハ一屬著シ。

4. 注射總量相等シキ時ハ $0.6 \mathrm{cc} \ni 1$ 週間注射スルョリモ0.3ec 72 週間持續スル方が其ノ作 用著明ナリ。

\section{第 5 䈱 副腎皮質「エキス」ノ雄性海猽新産仔生殖器/發育二及ボス影響}

第1 項 文嗝ノ概要 副腎卜生殖腺卜間二モ 亦緊密ナル內分泌的關係存スルハ多数學者ノ信ズ ル所ニシテ, Tandler (1910), Bittorf (1919) 等入 Addison 氏病/場合二崒丸八萎緶シ精子缺之症子 柬スキ見, Goldzieher(1912) 八小兒症（Infantilismus) *副堅/發育不全二起因スルモノト看做七 9. Schneider(1913), Mattias (1922), Schmidt (1924)，Dietrich u. Siegmond (1927)等八副䈌，

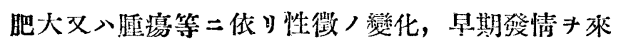
スト言へタ.

Jaffé u. Tannenberg (1927) 二據レバ猳性本陰陽 八副腎皮質放殖ノ結果二非ズシテ副㹂皮質卜生殖 腺卜ノ同時的畸形二過ギズト解セリ。

實驗的矿究二就テ見ルニLeupold (1920) 入副腎 皮質「コレステッン」減少ハ精上皮細胞ノ變性キ

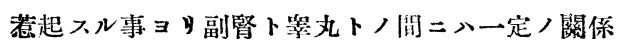
存スルモ/卜解シ, Watson (1923) モ亦略了同核 ナル見解キ有シタリ。

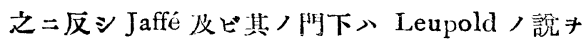
認容セズシテ雨者阔ニハ一定ノ關係ナキモノト主 張七リ．西村(1928)八副婜卜生㱠腺卜>關係二就 テハ明言シ得ズト䢎べ，衣笠(1930) 入副腎剔出入 幼若動物生愐器ノ分化, 䇾育キ阻害スル事ナク, 副 腎皮質ノ移植又八其ノ「メキス」キ注射入ルモ亦該 動物生殖器/分化, 谯有キ促進セシメズト言へリ。
Hewer (1922) ハ「ヨッア」三副腎皮質未Cortex 投與灭ハ「タポイド」注射キ行七シコ, 初メ八崒

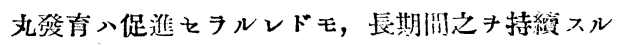
時ハ終二其ノ變性キ招來スルニ至ルト言フ. Amson (1913) > Cortisupren ノ注射二依雄性生殖器 ノ發有抑制セラ゙レタルキ見, Conner (1930) 八䟠

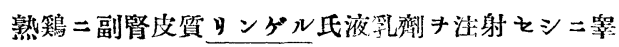
丸ハ菱縮シ且精子㳙失スルキ認メタッ。之二反シ $\vec{\jmath}$ Novak (1913), 井倉 (1927) 等八副腎剔出二 依りテ生殖器 發有不全キ㥕起七シメ, Riddle (1923) 八雄性鳩二副腎移植斗繰返入京二依yテ性 早期成熟卜生殖器ノ肥大卜キ惹起七シメタッ.Mc Kinley u. Fisher(1926) 入新鮮ナル副腎キ以ツテ 「ラッテ」キ飼盖シ崒九重量 $21.5 \%$ ダ 㙁加セルキ 見, Müller(1931) 及ビ Klein (1931) モ「アッテ」こ

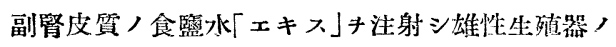

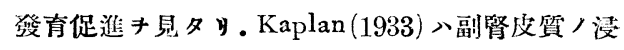
出液キ分チテ副餐皮質總物質ノ合有淩出液, 類脂 肪體ノ浸出液, 類脂肪體非含有浸出液及ビ Müller 氏法二依ル浸出液, 4 種トシ, 以上各種渌! 泣液 夫々「ラッテ」三注射シタル結果, 內眼的二ハ雌雄 雨性共二其八生殖器设有二一定ノ關你キ見出入能

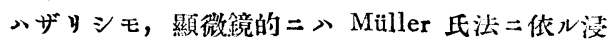
出液洼射例 脂肪體含有浸出液ノ注射例二八雄性生雅踌二ノミ 
其ノ發有促進セチルルキ磪メタット言フ。

\section{第2 項 驗 成 綪}

本實驗二於テモ動物ノ入手困難ナリシタメ所定洼射終了後 7 日日二屠殺セシモノノミニシテ 其ノ新產仔總數嚾カ $=11$ 頭ナリ.

第 5 表 副腎皮質「メキス」キ注射そシ例

\begin{tabular}{|c|c|c|c|c|c|c|c|c|c|c|c|c|c|}
\hline 箕 & & 驗 & I & & & II & & & III & & & IV & \\
\hline & & 驗 動 物 番 號 & 105 & 116 & 117 & 110 & 216 & 217 & 202 & 203 & 204 & 205 & 206 \\
\hline 生 & & 後 & 3 & 3 & 2 & 3 & 3 & 3 & 2 & 2 & 3 & 5 & 5 \\
\hline & & 注 & 76 & 75 & 70 & 90 & 85 & 85 & 65 & 73 & 80 & 115 & $\overline{114}$ \\
\hline & & 時 & 100 & 116 & 100 & 125 & 160 & 155 & 102 & 115 & 126 & 174 & 180 \\
\hline & & 率 & 1.32 & 1.55 & 1.43 & 1.39 & 1.88 & 1.82 & 1.57 & 1.58 & 1.58 & 1.51 & 1.58 \\
\hline & & 量 & 0.3 & & & 0.3 & & & 0.6 & & & 0.6 & \\
\hline $\mathrm{cc}$ & & 数 & 7 & & & 14 & & & 7 & & & 14 & \\
\hline & & 總 & 2.1 & & & 4.2 & & & 4.2 & & & 8.4 & \\
\hline & 射党 & 終了後屠殺汽ノ日呚 & 7 & & & 7 & & & 7 & & & 7 & \\
\hline & & 僛 & 0.10 & 0.10 & 0.08 & 0.09 & 0.13 & 0.16 & 0.09 & 0.12 & 0.12 & 0.16 & 0.18 \\
\hline & 䉽 & 側 & 0.10 & 0.10 & 0.07 & 0.10 & 0.13 & 0.16 & 0.08 & 0.12 & 0.13 & 0.16 & 0.19 \\
\hline & 7 & 均 & 0.10 & 0.10 & 0.08 & 0.10 & 0.13 & 0.16 & 0.09 & 0.12 & 0.13 & 0.16 & 0.19 \\
\hline & & 堆 加 率 & 0.91 & 0.91 & 0.73 & 0.83 & 1.08 & 1.33 & 0.82 & 1.09 & 1.18 & 1.33 & 1.58 \\
\hline g & 攝 & 腺 & 0.17 & 0.15 & 0.14 & 0.19 & 0.18 & 0.19 & 0.15 & 0.17 & 0.18 & $\overline{0.22}$ & 0.24 \\
\hline & 箸 & 率 & 1.00 & 0.88 & 0.82 & 1.00 & 0.95 & 1.00 & 0.88 & 1.06 & 1.06 & 1.16 & 1.26 \\
\hline & & 結 & $(+)$ & $(+t)$ & $(t+)$ & $(H)$ & $(+)$ & $(+)$ & $(H)$ & $(+t)$ & $(H)$ & $(+)$ & $(+)$ \\
\hline & & 间胞 肥 & $(-)$ & $(-)$ & $(-)$ & $( \pm)$ & $(-)$ & $(+)$ & $( \pm)$ & $(+)$ & $(+)$ & $(+)$ & $(+)$ \\
\hline & 筫 & 細 & $(-)$ & $(-)$ & $(-)$ & $(-)$ & $(-)$ & $(-)$ & $(-)$ & $(-)$ & $(-)$ & $(-)$ & $(-1)$ \\
\hline & & 最 大 外 徑 $(\mu)$ & 64 & 72 & 63 & 71 & 66 & 79 & 69 & 70 & 75 & 85 & 89 \\
\hline & 精 & 率 & 1.00 & 1.13 & 0.98 & 1.08 & 1.00 & 1.20 & 1.08 & $\mathbf{1 . 0 9}$ & 1.17 & 1.29 & 1.35 \\
\hline & & 腔 & (小) & (中) & (中) & (11) & $(\mathrm{r} / \mathrm{s})$ & (小) & (中) & (小) & $(11)$ & (小) & $(13)$ \\
\hline & 細 & 胞 & $(+t)$ & $(H)$ & $(t+)$ & $(\mathrm{tH})$ & $(H)$ & (世) & $(H)$ & $(H)$ & (世) & $(\mathrm{HH}$ & $(\mathrm{HI})$ \\
\hline & & 胞 & $(-)$ & $( \pm)$ & $(-)$ & $(+)$ & $(-)$ & $(+)$ & $(-)$ & $( \pm)$ & $(+)$ & $(H)$ & $(t+)$ \\
\hline & 1 & 精 娘 & $(-)$ & $(-)$ & $(-)$ & $(-)$ & $(-)$ & $(-)$ & $(-)$ & $(-)$ & $(-)$ & $(-)$ & $( \pm)$ \\
\hline & & 7 & $(-)$ & $(-)$ & $(-)$ & $(-)$ & $(-)$ & $(-)$ & $(-)$ & $(-)$ & $(-)$ & $|(-)|$ & $(-)$ \\
\hline & & 枝大外德 $(\mu)$ & 286 & 195 & 195 & 247 & 312 & 260 & 260 & 221 & 208 & 377 & 390 \\
\hline & & 率 & 1.38 & 0.94 & 0.94 & 0.99 & 1.25 & 1.04 & 1.25 & 1.06 & 1.00 & $\overline{1.51}$ & 1.56 \\
\hline & & 充實性 ノ モ & $(+)$ & $(+)$ & $(+)$ & $( \pm)$ & $(+)$ & $:(+)$ & $(+)$ & $(+)$ & $( \pm)$ & $( \pm)$ & $( \pm)$ \\
\hline & & 管㬶成形初期ノモノ & $(t+)$ & $(+)$ & $(+)$ & $(+)$ & $(\mathrm{H})$ & $(+)$ & $(\mathrm{H})$ & $(t+)$ & $(t+)$ & $(+t)$ & $(+)$ \\
\hline & 小 & 管腔何狄キモノ & (世) & $(\mathrm{H})$ & $(t+)$ & $(H+1)$ & $(t+)$ & $(H)$ & $(\mathrm{H})$ & $(t+)$ & $(\mathrm{Ht})$ & $(+t)$ & $\overline{(H)}$ \\
\hline & & 中等大ノモ， & (H) & $(\mathrm{HI})$ & $(+)$ & $(+)$ & $(\mathrm{HH})$ & $(++)$ & $(H)$ & $(+)$ & $(+)$ & (HI) & $(\mathrm{HH})$ \\
\hline & 葉 & 廣 & $(+)$ & $(-)$ & $(-)$ & $( \pm)$ & $(H)$ & $(+)$ & $(+)$ & $(-)$ & $( \pm)$ & $(+)$ & $(\mathrm{HI})$ \\
\hline & & 分泌物キ容ルルモ， & $(+)$ & $(+)$ & $(+)$ & $(+)$ & $(H)$ & $(+)$ & $( \pm)$ & $( \pm)$ & $(+)$ & $(+)$ & $(+)$ \\
\hline & & 菇シキモノ & $(+)$ & $(+)$ & $( \pm)$ & $(H)$ & $(+)$ & $(H)$ & $(H)$ & $( \pm)$ & $\cdot(-)$ & $(+\mathrm{H})$ & $($ W) \\
\hline
\end{tabular}

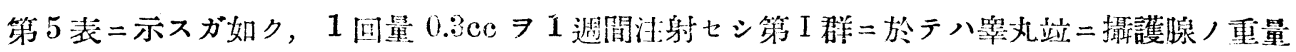

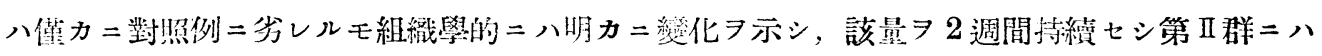
更二著明トナレリ。次 $=1$ 回量 $0.6 \mathrm{cc} \Rightarrow 1$ 週間洼射七シ第吕群二八其ノ所見第 1 群ヨリモ著明

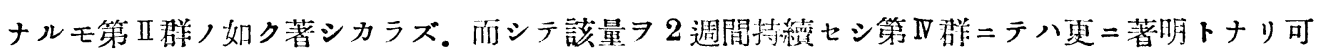
成り發育八促進七ラレタリ。

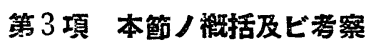

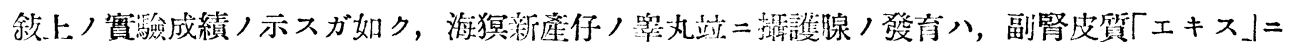

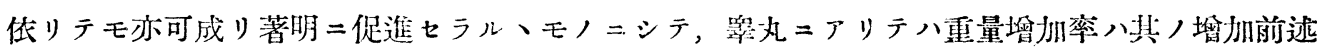


ノ腦下垂體前葉立立二後葉「エキス」例ニハ遙カニ及バザルモ，甲狀腺「エキス」例ト略 こ匹敵シ， 其ノ最大ナルモノハ1.587示七り。精細管最大外徑檑加率八其ノ最大ナルモノ 1.35 ナ。即チ 甲壯腺「エキス」例ト相伯仲シ, 是レ亦對照例， 1 沿尔二達セントス，而シテ造精機轉二就テ見 ルニ，精祖細胞及ビ精母細胞八㙫加シ，著明ナルモノニ八稀二精娘細胞へノ移行型ヨ示シ，造

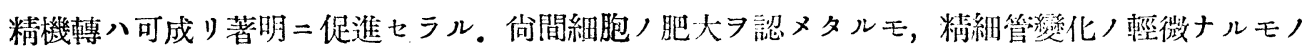
ニハ之ヨ見ル事ナク且其ノ增殖モ見ラレタル事ナシ。

次二攝護腺ニテハ重量增加率ハ最大ナルモ１.26ナリ．而モ腺小葉最大外徑㙕加率八本實驗

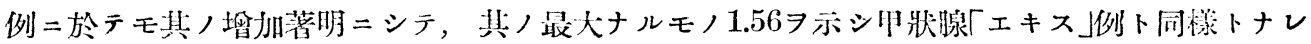

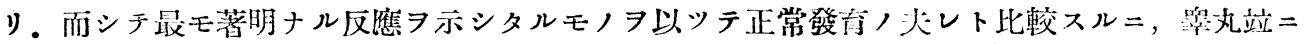
攝護腺八何レモ大體二於テ生後30日ノモノ=相賞セルガ如ク，生後27日ノモノ=比スレバ明カ ニえョタ優レルガ如シ。

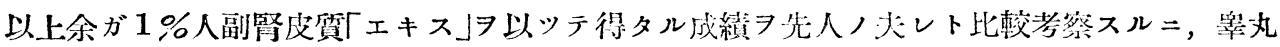

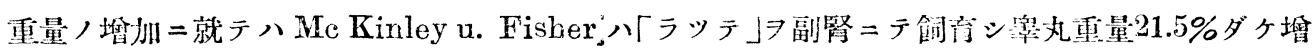

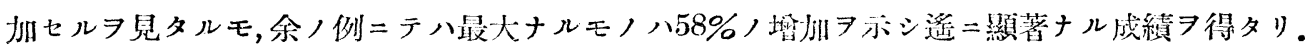
而シテ Amson ハ Cortisupren ノ注射ニ依りそガ抑测ア見，Conner ハ「リンゲル氏液乳劑」 注射二依り萎縮习見，Hewer ハ Cortex 又ハ「リボイド」ノ注射二依りテ曫性ヨ見タルモ，余 ノ例二於テ八全然斯カル所見ナカリキ。印チ余ノ成績ハ大體二於テ Ridule, Müller, Klein,

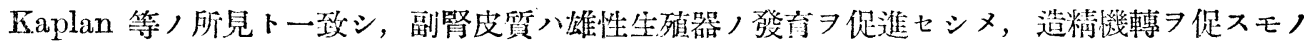
ト認容シ得ベシ.

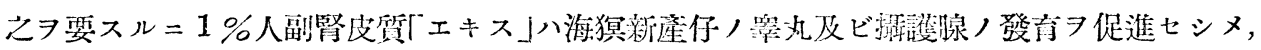

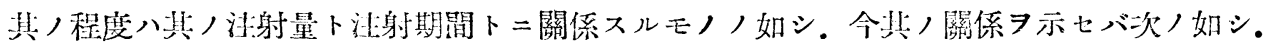

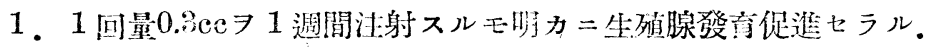

2 . 該量 72 週間持綽スル時ハ之八可成り著明トナル。

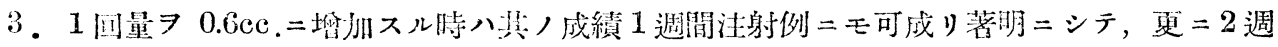

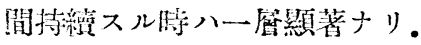

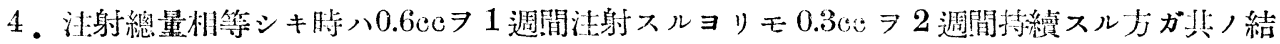
孯ハ著明ナリ。

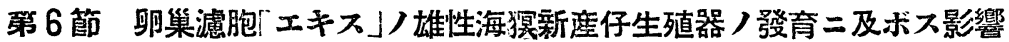

第1項 交献ノ䁻要 女性「ホルモン」》生理的 ニハ雄性生殖器ノ筑厺二必要ナルモノニ非ザレド モ，之ガ雄性生殖腺乃至八其ノ性徽二及ボス影留 ニ就テハ幾多ノ報告アリ。

1903年 Halban ハ性「ホルモン」ノ生殖器非特異 性キ注张シタルモ，1912年 Steinachカ Feminie-

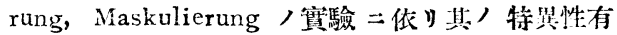
キル筫證シテ以來之キ迎侙フル著簇出シ, Laqueur, Jough u. Hart (1926) 八女性「ホルモン」ハ雄性

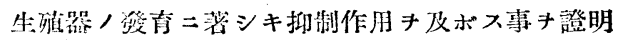
七y.

Beuthner u. Fels(1928) \ Menformon *注射. 
符 1 滈

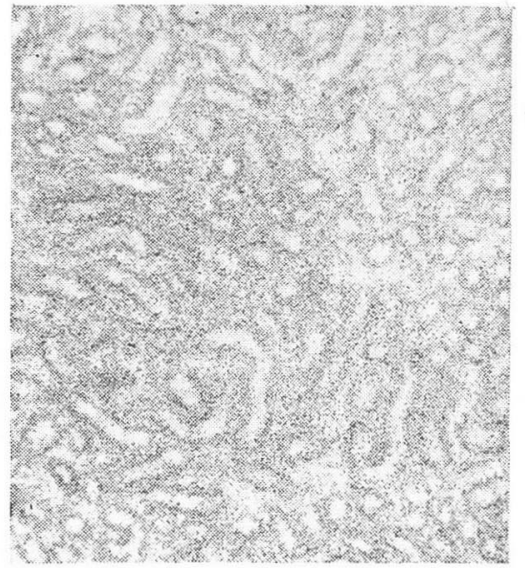

公 3 圆

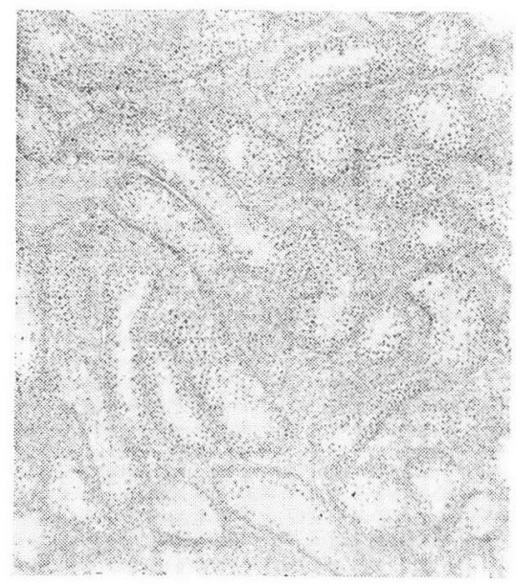

第 5 㽞

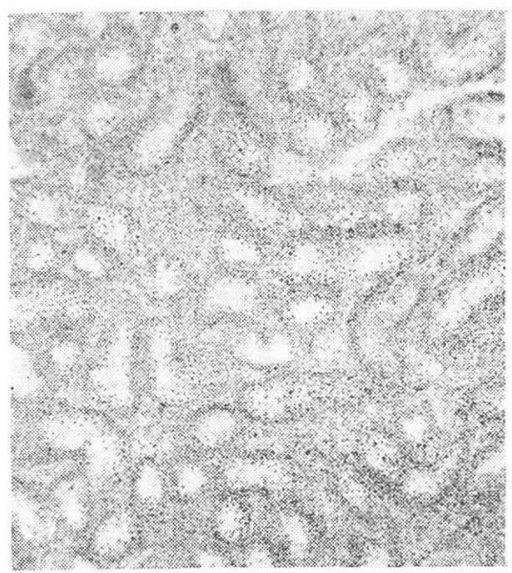

第; 2 嫡

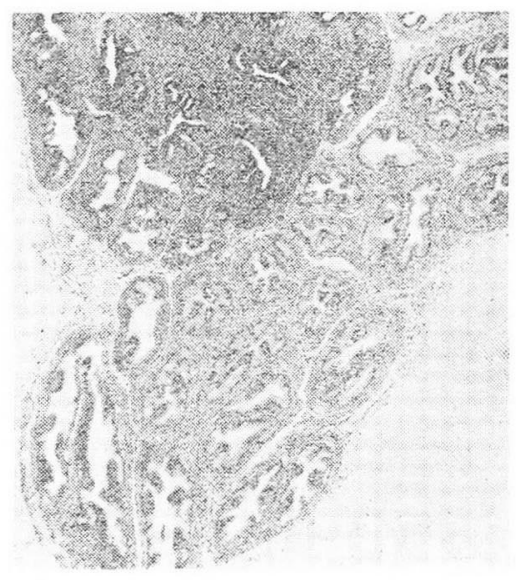

isi

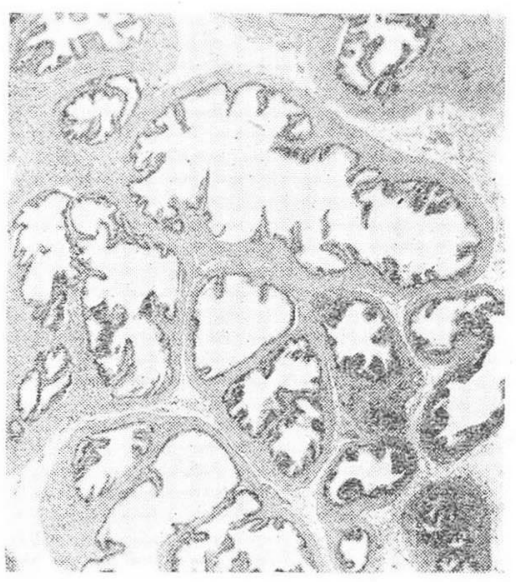

第 6 回蜀

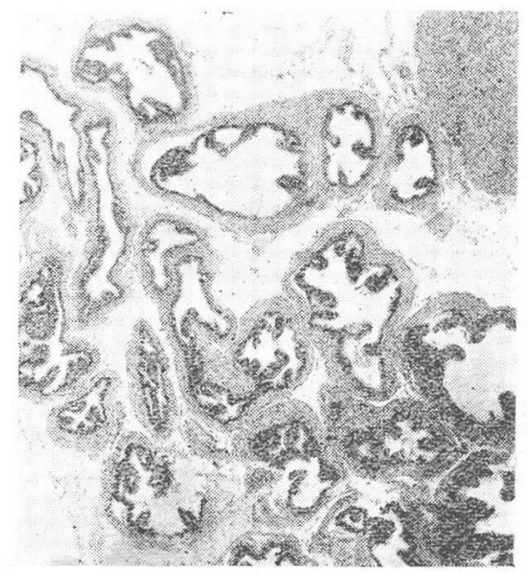


第 7 圖

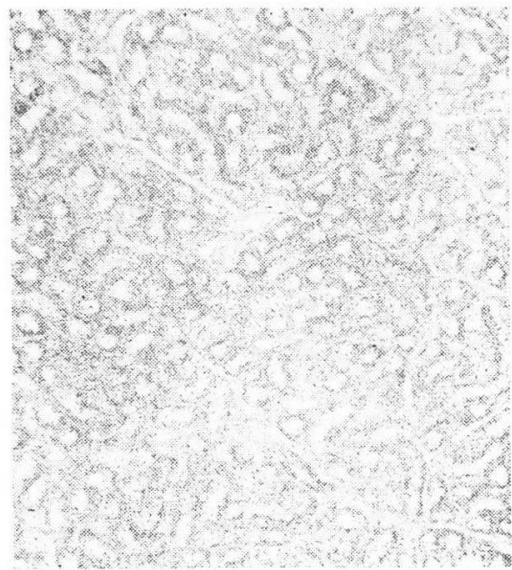

第 9 圖

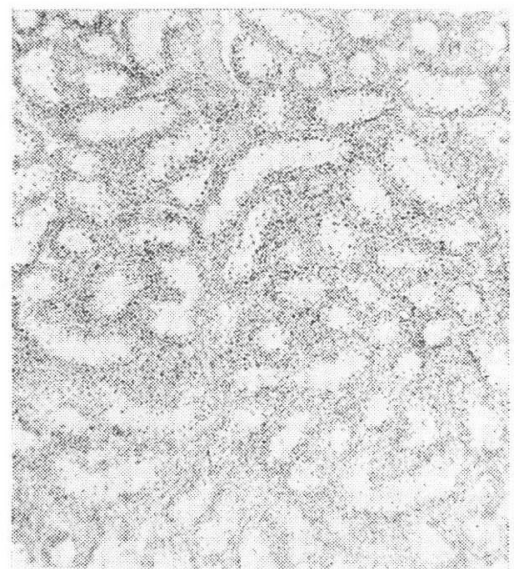

第 11 圖

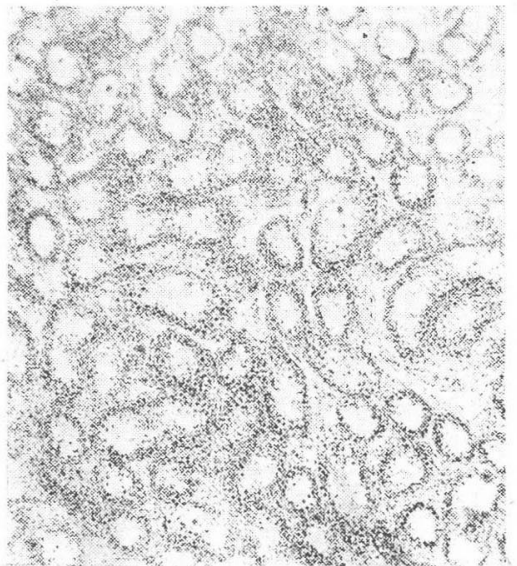

第 8 圖

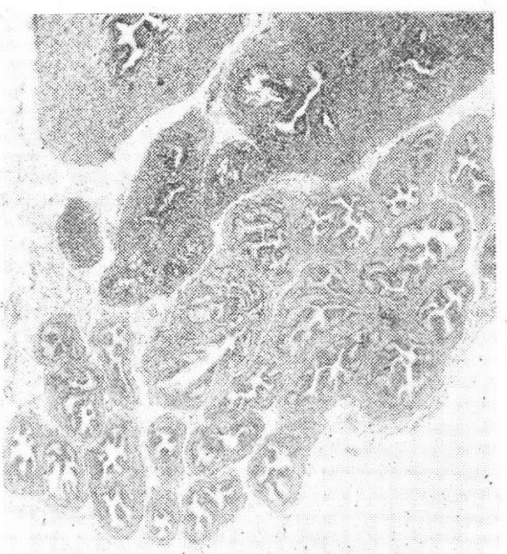

第 10 圖

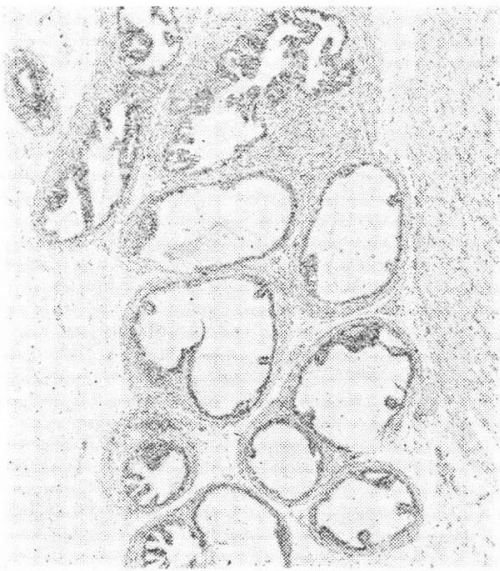

第 12 圖

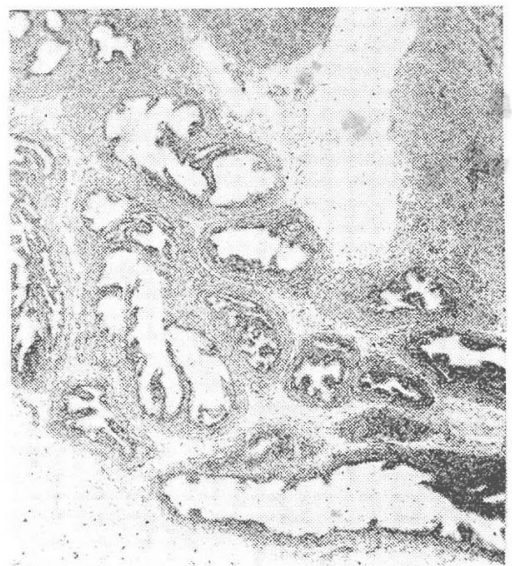


第 1.3 圖

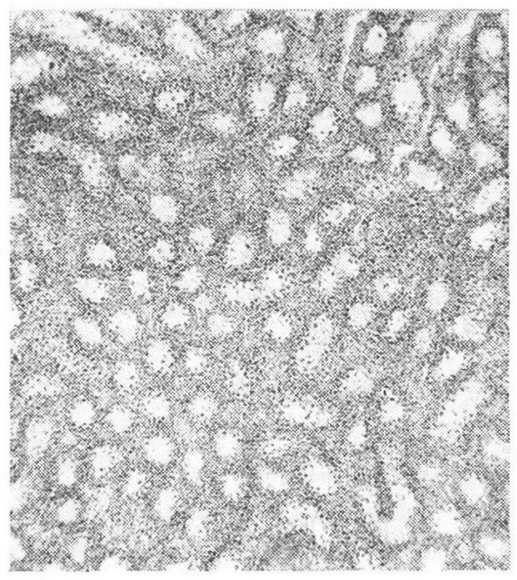

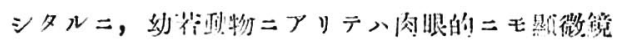

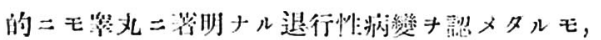

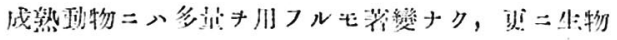

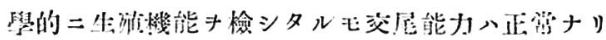

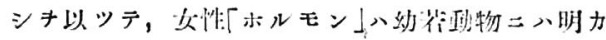

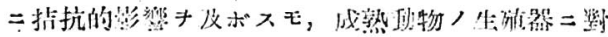

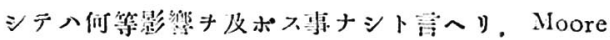

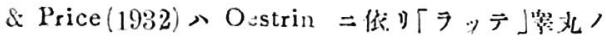

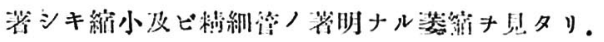
Spencer, Amour \& Gustavson(1.932) モ Oestrin ，抑制作月月見， Schoeller u. Gehre (1933)，Pepe (1933), Ilalpern \& Amour(1931), Kun (1933)

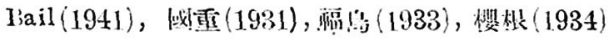

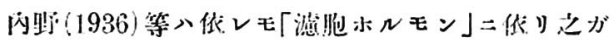
猢制飞ラルルキ思タリ。

一j Gardner(1937), Lacassagne(1934) 等入㻗

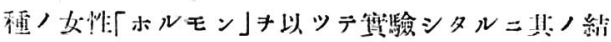

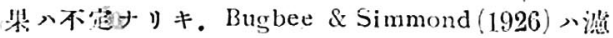

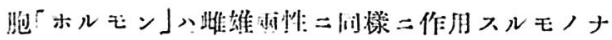
リト言七, Juhn, Allour \& Womack(1930) 八雌

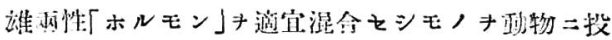

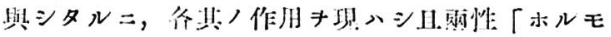

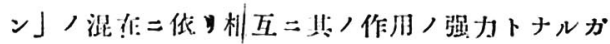

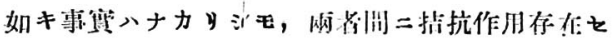
ザル事言登明セり。

Neumann(1931) 、Follikulin *幼㣺マウス」
第 14 圆

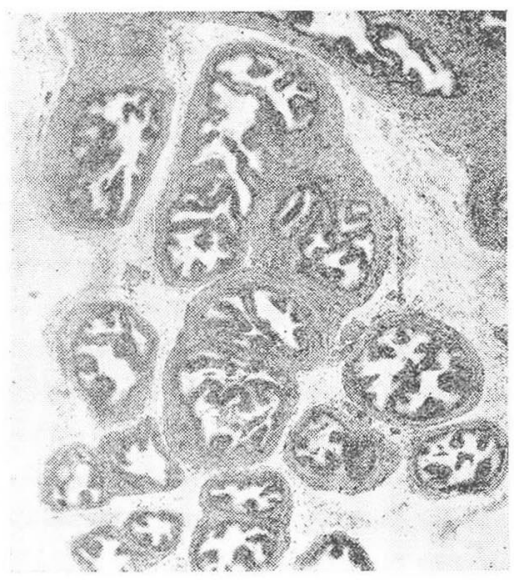

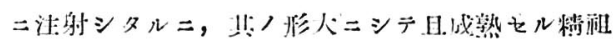

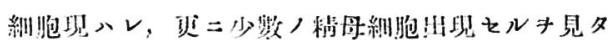

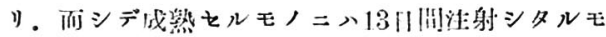

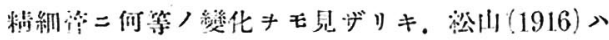

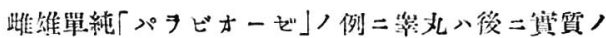

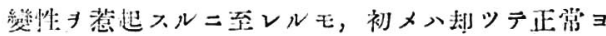

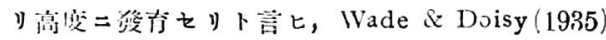
八生後 $21-25$ 日ハ「ッテ」=113-242日间二亘り Theelin 及ビ Theelol キ洁射シタルモ, 其/ 全

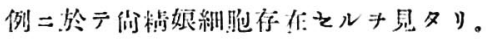

Laqueur (1932), Freud, Joug u. Laqueur(1933)

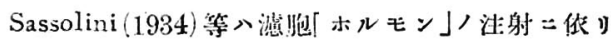

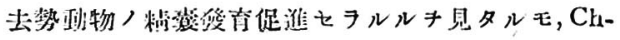
ampy u. Conjard (1937) , Follikulin /注射二依

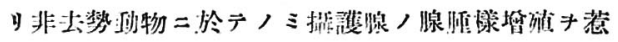
起をシメ得タ日卜芦フ。

Pighini, Giacomo, Delfini (1932) 等八牛照/卵

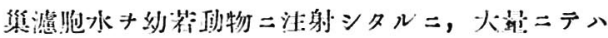

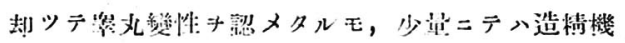
轉子促進をシムルモノナリト言七，Geréb(1931)

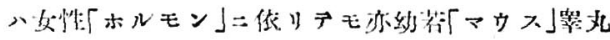

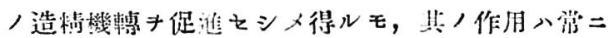

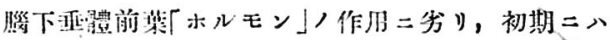

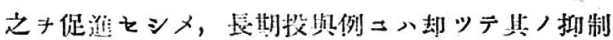
来來ス卜言へ日。 


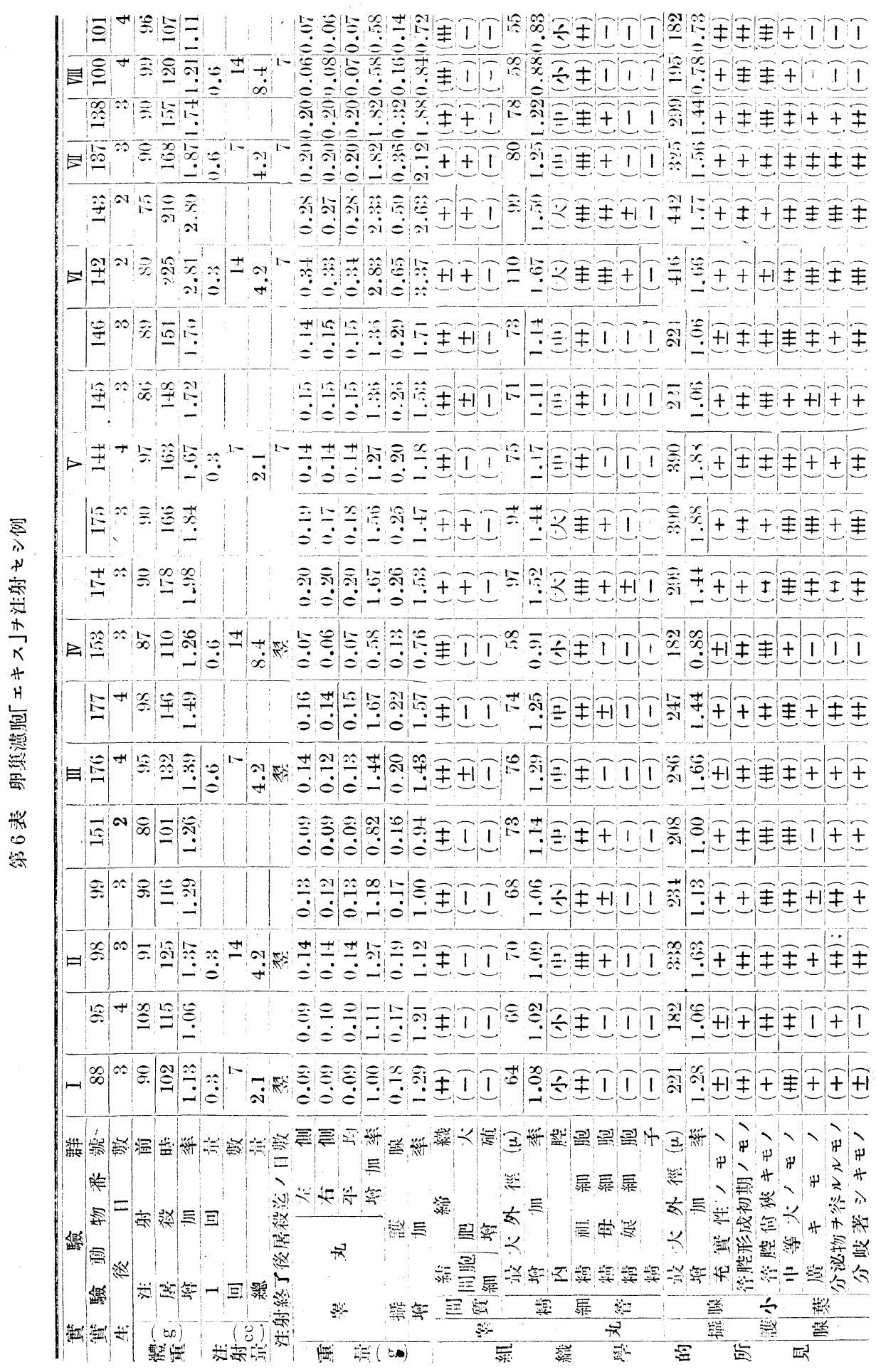




\section{第2項 震 驗 成 綪}

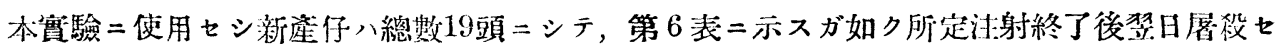

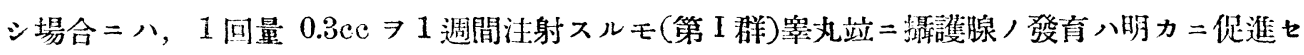

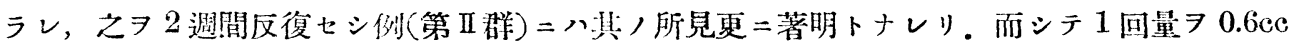

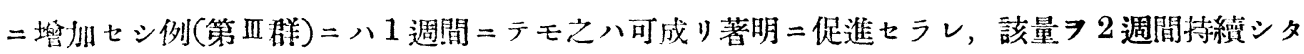

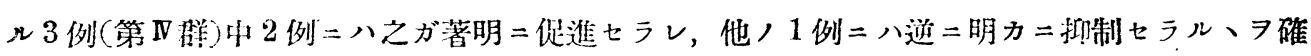
メタリ。

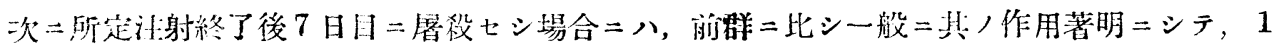

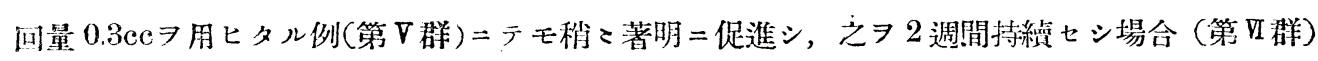

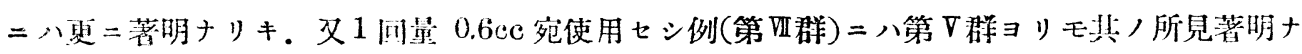

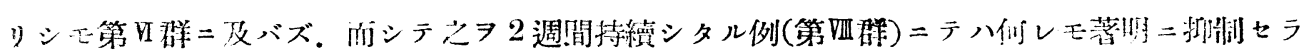
レタリ.

\section{第 3 項 本䉥ノ䌟括及ビ者察}

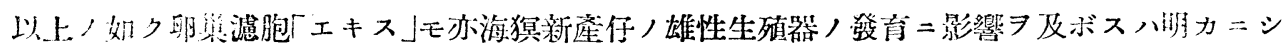

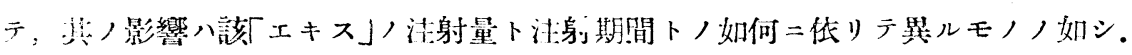

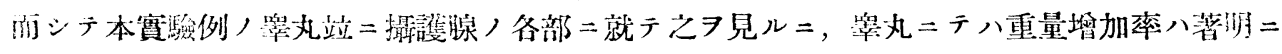

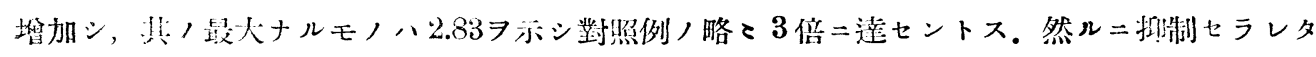

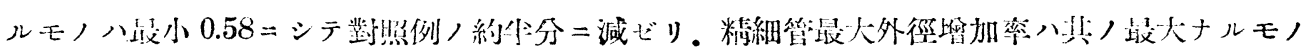

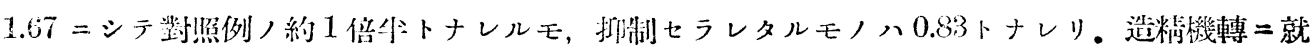

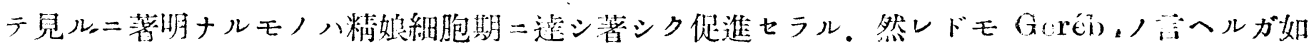

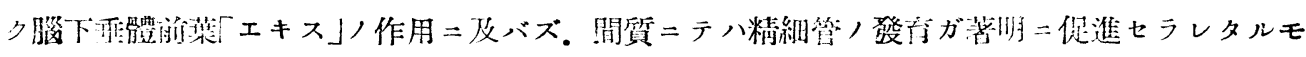

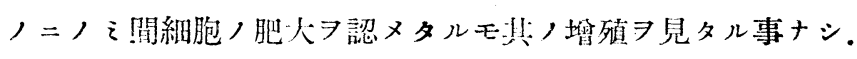

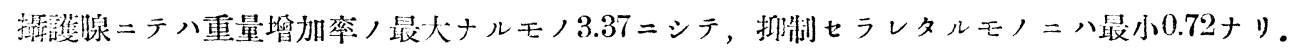

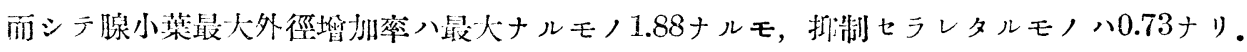

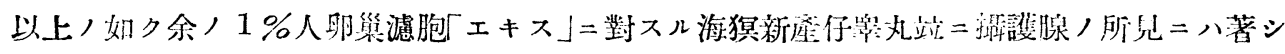

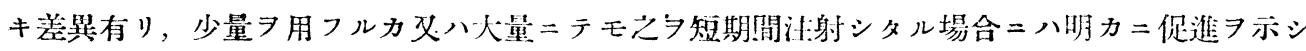

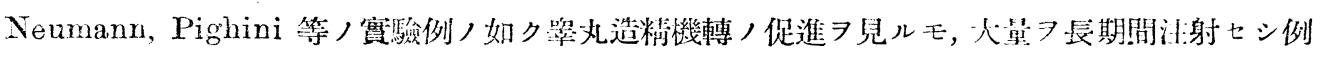

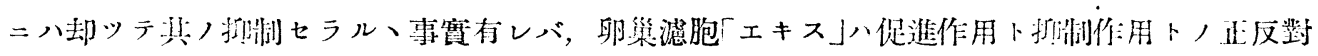

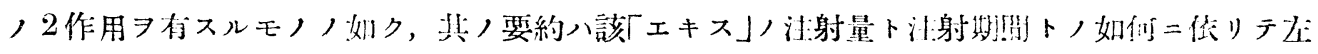

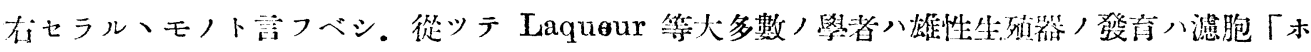
ルモン」ニ依りテ抑制七ラルト占ヒ，Geréb 八長期二亘りテ女性「ホルモン」ヨ投與スル時ハ 却ツテ其ノ排制ア來スト主張スレドモ, 余ノ成績ヨリ見ル時八大量习比較的長期間汁射スル事 ニ依リテ始メテ諸家ノ例ニ見ルガ如ク其ノ抑制七ラル、ヨ認メ得ルモノニシテ，卵留滤胞「ホ 
ルモン」ノ作用ハ極メテ複雜微妙ナリト言フベシ。

茲二於テ該「エキス」對シ最モ著明二反憵ヨ示シタルモノラ以ツテ正常發有ノ犬レト比較ス

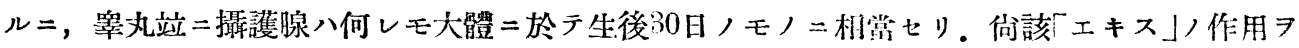
注射量ト注射期間トノ關係ヨリ示セバ次ノ如シ。

1. 1 回量 $0.3 \mathrm{ce} 71$ 週閒注射スルモ生殖腺，發青八可成り著明二促進七ラレ，其， 2 週间 持續例ニハ一層著明ナリ。

2. 1 回量 $0.6 \mathrm{ec}$ 宛 7 注射スル時ハ 1 週間反復スルモ可成リ著明二之ガ促進セラル。

3. 1 回量 $0.6 \mathrm{cc}$ フ 2 週間持續スル時ハ却ツテそハ抑制七ラル。

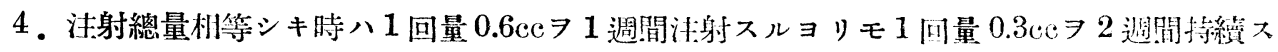
ルすガ其ノ作用顯著ナリ。

\section{第4 章 考按}

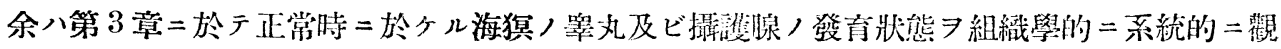
察スルト共二，凡ソ生殖腺ノ發育二關係ヨ有スベキ諸種「ホルモン」劑フ使用シ，之等が海猽新

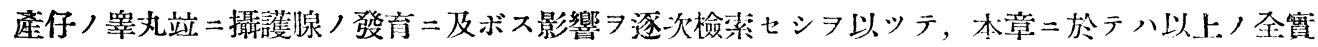
驗成績

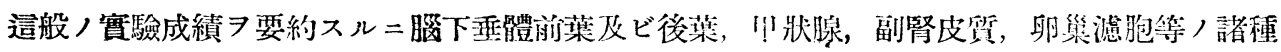

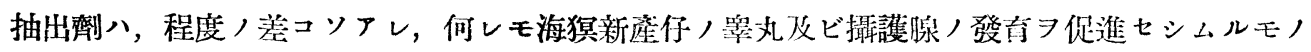
ニシテ，㡎育促進，程度八夫等ノ注射量立二注射期問=關係七ルモノノ如ク，一般二注射期間 相等シキ時ハ少量 7 用フルヨリモ大量 7 用ヒタル例二效果八著明ニシテ, 沬射總量机等シキ時

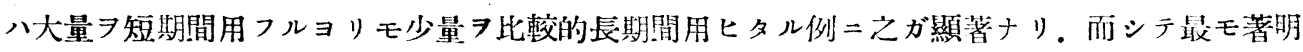

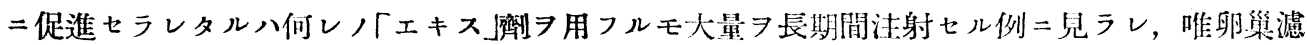
胞「エキス」ノえハ之ト趣フ罪ニシ少量フ長期間用フル時が最モ著明ニシテ，大量短期閒使用例 ニ八可成り促進セラレ，大量長期閐使用例ニハ却ッテ抑制

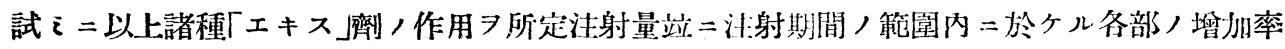
ノ最大值ヨ以ツテ比較スルニ次ノ如シ。

體重增加率八最大ナルモ，卵巢滤胞「エキス」注射例，2.81，次イデ膃下垂體前葉「エキス」例 ，2.80，以下脑下垂體後葉「エキス」例，2.10, 甲狀腺「エキス」例，2.05，副腎皮質「エキス」例， 1.88 ノ順トナレリ。

睪丸二就テ見ル二重量增加率八最大ナルモノ前葉「エキス」汒射例ノ3.64, 次イデ卵策濾胞「エ キス」例 $/ 2.83$, 後葉「エキス」例/1.83，妇狀腺「エキス」例ノ1.67，副腎皮質「エキス」例ノ1.58

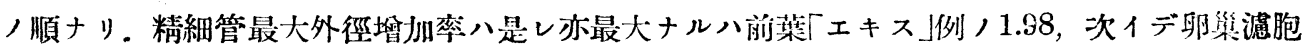

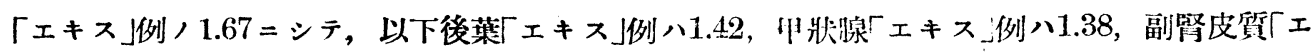
キス」例ハ1.3ラトナレリ。造精機轉二就テ見ルニ最モ著明ナル八前葉「エキス」例ニシテ，余 
例ニテハ定型的ナル精子，發生

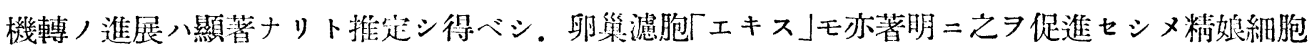
ヨ出現セシムルモ的葉「ェキス」例＝及バズ，更二後葉「エキス」例，叫狀腺「エキス」例，副監皮

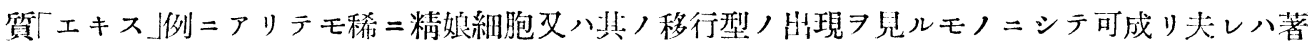
明ナリト踓モ，夫等ノ優劣ハ此ノ場合明確ニハ決定シ難シ。間質ノ變化二就テえヨ胃ル二閒細

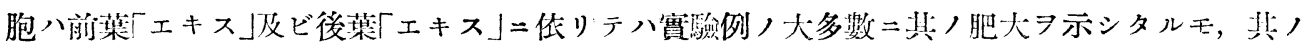

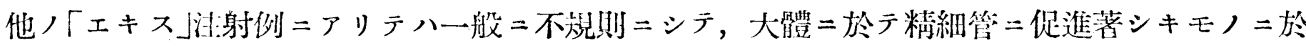
テノi肥大スルョ見タリ。余ノ例二於テハ何レノ實驗例二モ其ノ增殖

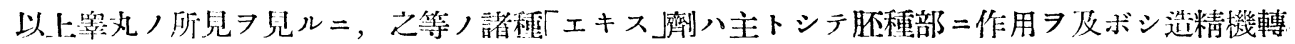

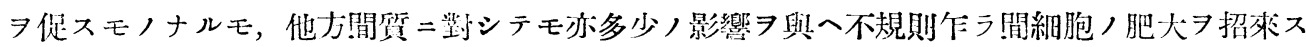

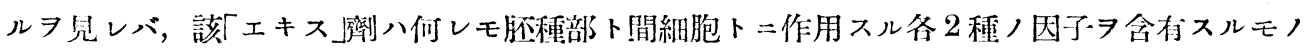
ノ如シ。问モ上述ノ如ク閒細胞ノ變化が不替則ナリシハ後者二及ボス因子ノ含有七ラル、事整少 キカ或八其ノ作用ノ弱キカ何レニカ因ルモノナランモ，更二動物ノ幼若ニシテ該組織ノ未熟ナ ルタメ反應弱キ事モ亦其ノ一因ナルベシ。

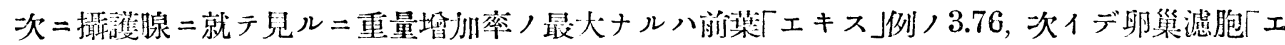

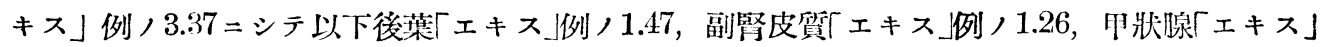
例ノ 1.17 ノ順ナリ。腺小葉最大外徑增加率八其ノ最大ナルモノ亦前葉「エキス」例ニシテ 2.387

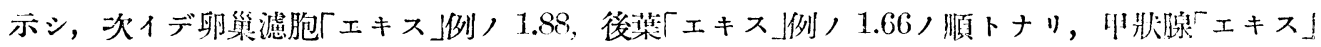
例及ビ副腎皮質「エキス、挒八共二 1.56 トナレリ。而シテ腺小葉分化ノ程度二就テ見ル二，之 二於テ八啐丸，造精機轉二見ラル、ガ如キ劃然タル區別ラ見出ス事能ハザリシモ，余ガ腺小葉 Э其ノ組織學的造構二基キテ分類セシ 7 型ヨ基礎トシテ考察スル時ハ必ズシモ困難ナルモノ= 非ズ，即チ分泌物ヨ签ル、モノ及ビ分岐著シキモノ八，管腔廣キモノト共二發育モ分化モ促進

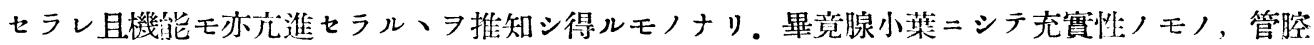
形成初期ノモノ及ビ管腔傸キモノ等ノ如キハ未ダ分化セザルカ或八其ノ低級ナルモノト解シ好

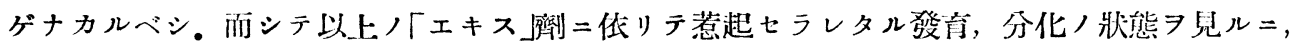

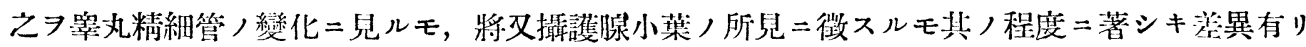
テ全ク反應习受ケザリシ觀有ルモ，ト著明二變化ヨ示シタルモノトガ混合セリ。斯カル事實八 就中大量ノ「キス」ヨ比較的短期間洼射七シモノニ著明ナリキ。之ハ正常發有ノ夫レガ比較的

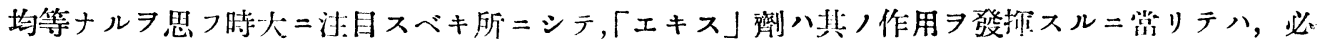

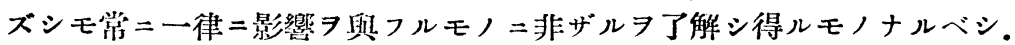

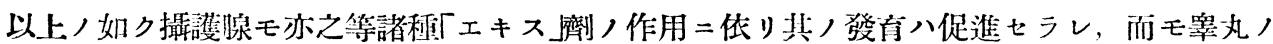

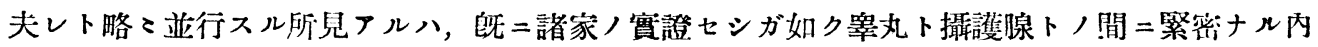
分泌關係ガ存在シ，攝護腺ノ變化八鋅丸ノ機能立進二基ク二次的作用 $=$ 因ルモノト解スル時容 
易二首肯シ得ルガ如シ。

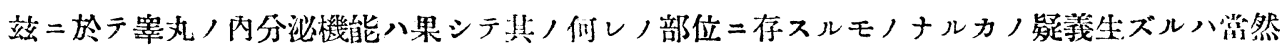

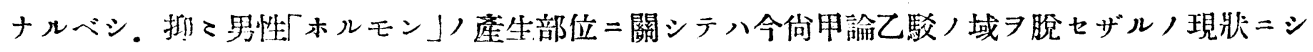
テ，就中間細胞八最モ諭护，中心トナリ，古來幾多，學者=依種々研究セラレ，Steinach， 如キハ所謂若返り法二理論的根據 ヨ推定スルニ至リタルモ, 其ノ後之ガ誤解

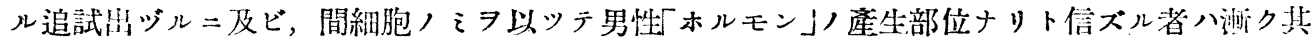

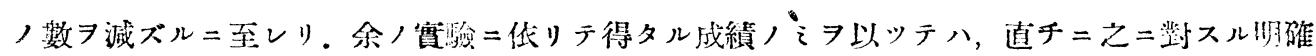

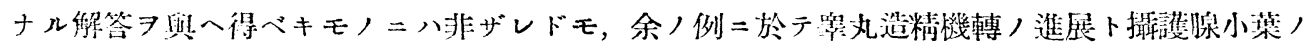

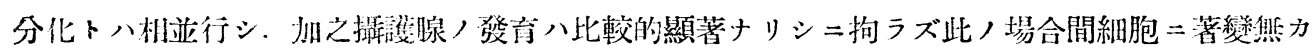

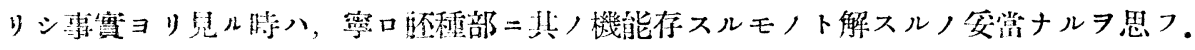

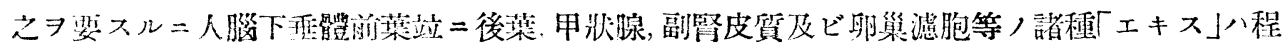

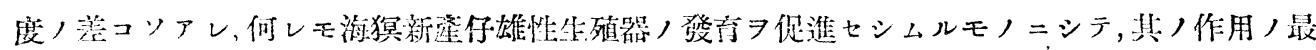

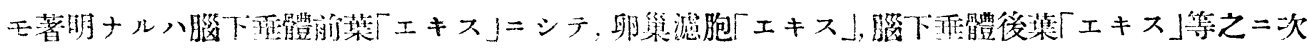

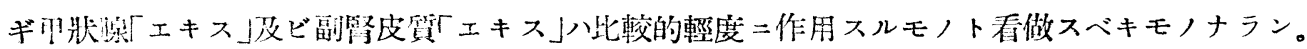

\section{第 5 章 總括站二結論}

本研栄二於テ得タル成縝, 概要 7 逃ブレバ次ノ如シ。

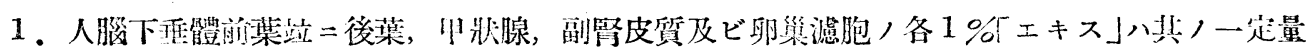

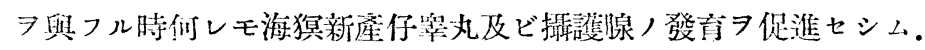

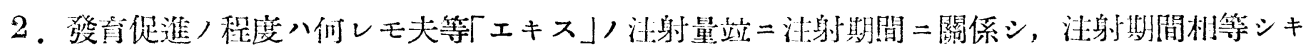
時ハ少量使用例ヨリモ大量使用例二著明ニシテ，沚射總量相等シキ睆八大量短期間使用例ヨ

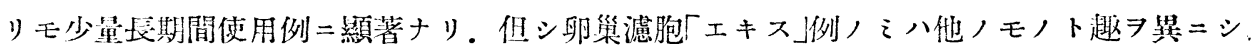

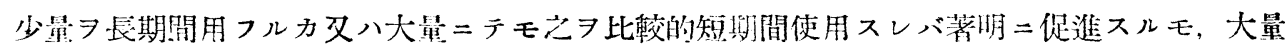
長期蹋使用例ニハ却ツテ扣制セラル、ラ是ル。

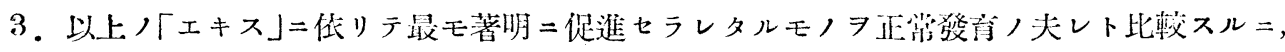

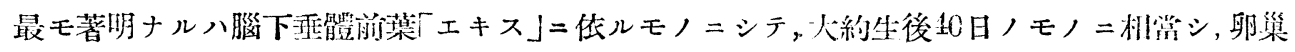

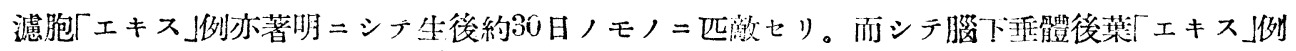

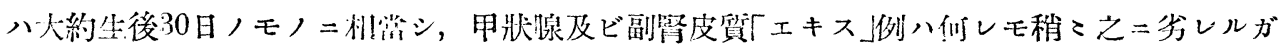
如シ。

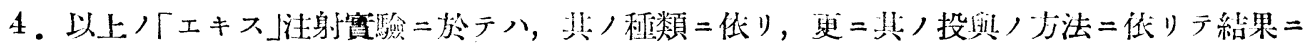

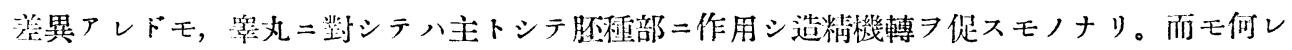

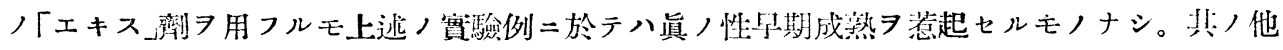

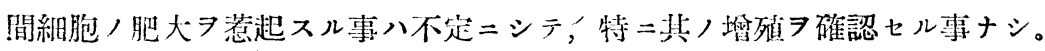

5. 琴謢腺ニ對シテハ主トシテ腺小葉二作用シ，腺小葉八增大シ圓形トナリ又ハ分肢ス。晌シ 
テ管腔八擄張シ更二队

6。虷丸立立二攝護腺, 發育ハ名ンド常ニ相並行シテ促進セラル、モノ/如シ。

以上ノ成績ニ基ヅキ次ノ如ク結論セント欲ス。

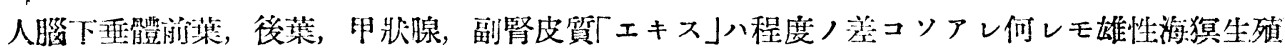
器，發夺 $\ni$ 促進七シム。而シテ卵巢滤胞「エキス」八其ノ注射量站二洼射期間ノ如们二依リテ或 ハ著シクえヨ促進セシメ或ハ逆ニえヨ抑制ス。

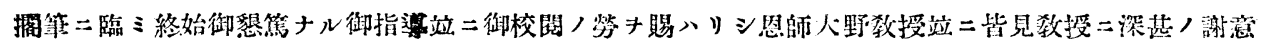
斗表入.

\section{主 要 文 献}

1) Amson: Endokrinol. Bd. 9, S. 241, 1931. 2) Aschner: Hirsch's Handb. d. inner. Sekr. Bd. 2, S. 2777, Leipzig, Kabitzsch, 1927. 3) Aschmer: Arch. Gynāk. Bd. 97, S. 200, 1912. 4) Ascoli n, Legmani : Münch. med. Wsch. Nr. 10, S. 518, 1912. 5) Bail: Frankf. Z. Path. Bd. 55, S. 14, 1941. 6) Behrenroth: Dtsch. Arch. klin. Med. Bd. 113, S. 393, 1914 . 7) Belawenetz: $\nabla$ irchows Arch. Bd. 274, S. 585, 1930. 8) Belawemetz: Anat. Anz. Bd. 65̄, S. 144, 1928. 9) Beuthner n. Fels: Endokrinol. Bd. 2, S. 406, 1928. 10) Biedi: Arch. Gynäk. Bd. 132, S. 167, 1927. 11) mittorf: Berl. klin. Wsch. Nr. 33, S. 776, 1919. 12) Bugbee a. Simmond: 內野二據 . 13) Champy u. Coujard: Zit. n. Róssle u. Zahler. 14) Chrustalew : Münch. med. Wschr. Nr. 29, S. 1621, 1913. 15) Collip, Melye u. Thomson: Virchows Arch. Bả. 290, S. 34, 1933. 16) Comner: Zit. n. Kaplan. 17) Diamontopolus: Zit. n. Jaffé u. Berberich. 18) Dietrich a. Siesmond: Henke-Lubarsch's Handb. d. spez. path. Arat. u. Histol. Bd. \&, S. 951, Berlin, Springer, 1920. 19) Disderlein : Beitr. path. Anat. Bd. 83, S. 92, 1930. 20) Eiselsberg: Zit. n. Asher. Hirsch's Handb. d. inner. Sekr. Bd. 2, S. 168, Leipzig, Kabitzsch, 1927. 21) Evans a. 1.ong: Anzt. Rec. Vol. 21, P. 61, 1921. 22) Evans a. Simpson: Anat. Rec. Vol. 32, P. 206, 1926. 23)Freud, Jong u. Laquenr: Ref. in Berichte u. d. g. Physiol. u. exper. Pharmakol. Bd. 73, S. 163, 1933. 24)福島: 臨床產科, 第

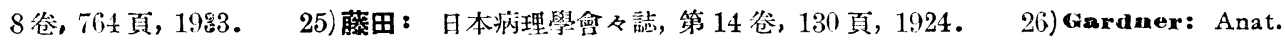
Rec. Vol. 68, P. 339, 1937. 27)Geréb: Endokrinol. Bd. 9, S. 119, 1931. 28) Goldzieher: Zit. n. Wegelin. 29) Halban: Arch. Gynäk. Bd. 70, S. 205, 1903 . 30) Malporn a. Amonr: Ref. in Berichte u. d. g. Physiol. u. exper. Pharmakol. Bd. 85, S. 153, 1935. 31) 瑧: 來尔醫祭 會雜誌, 第 29 能, 647 頁, 1915. 32) 速水：日本病理學會々誌, 第 9 参, 96 頁, 1919. 33) Hewer : Brit. med. Journ. Vol. 1, P. 138, 1922. 34) Hopmeister: Zit. n. Asher. 35)hohlweg u. Junkmann： Klin. Wschr. Nr. 8, S. 321, 1932. 36)井畣: 日本内分泌學會雅誌, 第 3 夋, 610 頁, 1927. 37)石祜: 日本病理學會々誌, 第 3 鈆, 181 頁, 1914. 38) Jafré a. Marine： J. of exper. Med. Vol. 38, P. 107, 1923. 39) Jafré u. Trannembers: Hirsch's Handb. d. inner. Sekr. Bd. 1, S. 473, Leipzig, Kabitzsch, 1927. 40) Juhn, Amour a. Womnek: Amer. J. Physiol. Vol. 95,

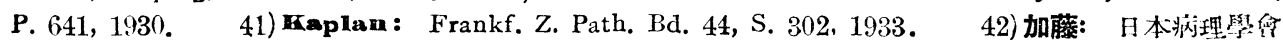
々誌, 第 10 兊, 26 頁, 1920. 43) klein: Endokrinol. Bd. 9, S. 401, 1931. 44) Koeh : Münch. med. Wschr. Nr. 36, S. 1501, 1936. 45) krezeneeky: Arch. mikrosk. Anat. u. Entw.-mechan. Bd. 101, S. 621, 1924. 46) Kraus: Henke-Lubarsch's Handb. d. spez. path. Anat. u. Histol. Bd. 8, S. 810, Berlin, Springer, 1926. 47) Kraus n. Holzer: Virchows Arch. Bd. 251, S. 253, 1927.

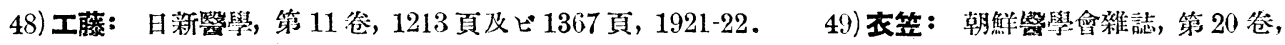
116 頁, 1930. 50) Kun: Endokrinol. Bd. 13 , S. 311, 1933. 51) 國重: 岡山醫學會雜誌, 第 43 夋, 1150 頁, 1931. 52) Laccassagne: Zit. n. Bail. 53) Lanz: Zit. n. Jaffé u. Tannenberg. 54) Laqneur: Ref. in Berichte u. d. g. Physiol. u. exper. Pharmakol. Bd. 72, S. 154, 1933. 55) Laquenr, Hart u. jough: Dtsch. med. Wschr. Nr. 30, S. 1247, 1926. 56) Leupold: Beitr. 
path. Anat. Bd. 69, S. 305, 1921.

57) Leupold: Ref. in Zbl. Path. Bd. 31, S. 390, 1920-1921. 58) cenpold: Ref. in Zbl. Path. Bd. 31, S. 571, 19201921. 59) Lenpold: Veröffentl. a. d. Kriegs-u. Konstitutionspathol. Jena, Fischer. H. 4, 1920. 60) Marchand: Münch. med. Wschr. Nr. 29, S. 1440, 1906. 61) Mattias：Virchows Arch. Bd. 236. S. 446, 1922. 62) 松山：日新 矪學，第 8 卷, 1765 頁, 1916. 63) Mekinley m. Fisher： Zit. n. Bayer. 64) Mislawsky : Zit. n. Belawenetz. 65)宮村：日本內分泌學會雜誌，第 4 卷，2012 頁，1928.

66) Moore $\mathbf{m}$. Price: Amer. J. Anat. Vol. 50, P. 13, 1932. 67) Miiller: Endokrinol. Bd. 8, S. 5, 1931. 68) Nenmann : Ref. in Żbl. Gynäk. Bd. 20, S. 1639, 1931. 69)西村：日本內分泌學會雜誌. 第 4 兊, 1942 頁, 1928. 70) Novak：Arch. Gynäk. Bd. 101, S. 36, 1913. 71)大西：日本內分泌 學會雜誌, 第 7 叁, 857 頁, 1931. 72) Pepe: Ref. in Berichte u. d. g. Physiol. u. exper, Pharmakol. Bd. 79, S. 417, 1934. 73) Pighini : Zit. n. Belawenetz. 74) Pighini, Giacomo, Delfini : 內野二據ル。 75) Ranther: Oppel's Lehrb. d. vergl. mikrosk. Anat. d. Wirbelt. Bd. 4, S. 289, Jena, Fischer, 1904. 76) Remotti : Zit. n. Belawenetz. 77) Ridale: Zit. n. Kaplan. 78) Romeis: Arch. Entw.-mechan. Bd. 37, S. 183, 1913. 79) Rössle u. Zahler: Virchows Arch,

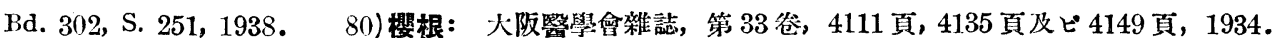
81) Saller: Z. Anat. u. Entw.-mechan. Bd. 80, S. 579, 1926. 82) Sassolini : Ref. in Berichte u. d. g. Physiol. u. exper. Pharmakol. Bd. 84, S. 644, 1935. 83) Sehmidt: Virchows Arch. Bd. 251, S. 8, 1924. 84) Schinz w. Slotopolsky: Virchows Arch. Bd. 248, S. 285, 1924. 85) Schneider: Verh. dtsch. Path. Ges. 1923. 86) Schoeller u. Gehre: Biochem. Z. Bd. 264, S. 352, 1933. 87) Smith: Amer. J. Physiol. Vol. 65, P. 277, 1923 88) Smith: Amer. J. Anat. Vol. 40, P. 159, 1927. 89) Smith: J. amer. med. Assoc. Vol. 88, P. 158, 1927. 90) Spemcer, Amour a. Gustavson: Amcr. J. Anat. Vol. 50, P. 129, 1932. 91) steimach: Pflügers Arch. Bd. 144, S. 71, 1912. 92) Steimach u. Kun: Med. Klin. Nr. 14, S. 524, 1928. 93) Steimach u. Kun: Dtsch. med. Wschr. Nr. 26, S. 1107, 1927. 94lsternbere: Beitr. path. Anat. Bd. 67, S. 275, 1920. 95) stieve: Möllendorff's Handb. d. mikrosk. Anat. d. Menschen. Bd. 7/2, Berlin, Springer, 1930. 96) Tandler: Wien. klin. Wschr. Nr. 13, S. 459, 1910. 97) Trendelenbura: Die Hormone, ihre Physiol. u. Pharmak. Bd. 1, Berlin, Springer, 1929. 98)角田：日本病理學會々誌, 第 12 兊, 359 頁, 1922. 99)辻：井倉二據ル． 100)內野：日本內 分泌學會雜誌，第 12 卷, 45 頁, 1936. 101) voss u. Ioewe：Pflügers Arch. Bd. 218, S. 604, 1928. 102) Wade a. Doisy: Endocrinology Vol. 17, P. 128, 1936. 103)watson: J. of Physiol. Vol. 58, P. 240, 1923-24. 104) zomdek u. Aschheim: Arch. Gynäk. Bd. 130, S. 1, 1927. 105 zondek w. Aschheim: Klin. Wschr. Nr. S, S. 1322, 1927. 106)zondek u. Aschheim: Klin. Wschr. Nr. 1, S. 8, 1928. 107) zondek: Klin. Wschr. Nr. 6, S. 245, 1930. 108) Zondek : Klin. Wvschr. Nr. 9, S. 393, 1930.

\section{附 圆說明}

案丸組絨入總デ擴人 80 倍，㨨護腺ノ夫レハ50倍 こテ鏡檢をリ.

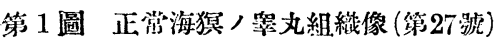

第 2 圆同摆護腺組織像 (何レモ生後23日目)

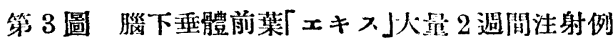

(7日日二屠殺) 海猽罢丸組織像(第135禠)

第 4 圖问辈護腺組織像

第 5 圆 卵巢濾胞 $匚$ ×

日目屠殺) 海猽票丸組織像(第 143 㾔)

第 6 圖 同攝謢腺組織像

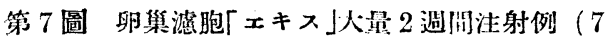

日目二屠殺) 海猽崒丸組織像(第101號)

第 8 圖同攝護㟫組織像

第 9 圆 腦下垂體後葉 $\Gamma \neq$ ス」大量 2 週䦌注射例

(7日目 $=$ 屠殺) 海猽蛙丸組織像 (第191號)

第 10 圆同攝護腺組織像

第11圆 甲狀腺「 $x \neq$ ス大量 2 週閌法射例（7日

目二屠殺) 海猽票丸組㵶像 (第149號)

第I2圖 同琶護腺组織像

第13圖 副腎皮質「×キ>」大量 2 邀闲注射例 $(7$

日目二屠殺) 海猽案丸組䄉像 (第206躆)

第14圖同攝護腺組織像 